Atmos. Chem. Phys., 17, 14853-14869, 2017

https://doi.org/10.5194/acp-17-14853-2017

(C) Author(s) 2017. This work is distributed under

the Creative Commons Attribution 3.0 License.

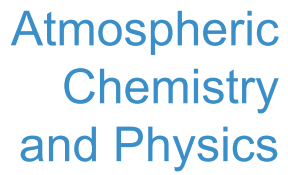

(c) (P)

\title{
Mountain waves modulate the water vapor distribution in the UTLS
}

\author{
Romy Heller $^{1}$, Christiane Voigt ${ }^{1,2}$, Stuart Beaton ${ }^{3}$, Andreas Dörnbrack ${ }^{1}$, Andreas Giez $^{4}$, Stefan Kaufmann $^{1}$, \\ Christian Mallaun $^{4}$, Hans Schlager ${ }^{1}$, Johannes Wagner ${ }^{1}$, Kate Young ${ }^{3}$, and Markus Rapp ${ }^{1,5}$ \\ ${ }^{1}$ Deutsches Zentrum für Luft- und Raumfahrt, Institut für Physik der Atmosphäre, Oberpfaffenhofen, Germany \\ ${ }^{2}$ Johannes-Gutenberg-Universität Mainz, Institut für Physik der Atmosphäre, Mainz, Germany \\ ${ }^{3}$ National Center for Atmospheric Research, Boulder, Colorado, USA \\ ${ }^{4}$ Deutsches Zentrum für Luft- und Raumfahrt, Flugexperimente, Oberpfaffenhofen, Germany \\ ${ }^{5}$ Ludwig-Maximillians-Universität München, Meteorologisches Institut München, Munich, Germany
}

Correspondence: Christiane Voigt (christiane.voigt@dlr.de)

Received: 10 April 2017 - Discussion started: 18 April 2017

Revised: 6 October 2017 - Accepted: 25 October 2017 - Published: 14 December 2017

\begin{abstract}
The water vapor distribution in the upper troposphere-lower stratosphere (UTLS) region has a strong impact on the atmospheric radiation budget. Transport and mixing processes on different scales mainly determine the water vapor concentration in the UTLS. Here, we investigate the effect of mountain waves on the vertical transport and mixing of water vapor. For this purpose we analyze measurements of water vapor and meteorological parameters recorded by the DLR Falcon and NSF/NCAR Gulfstream V research aircraft taken during the Deep Propagating Gravity Wave Experiment (DEEPWAVE) in New Zealand. By combining different methods, we develop a new approach to quantify location, direction and irreversibility of the water vapor transport during a strong mountain wave event on 4 July 2014. A large positive vertical water vapor flux is detected above the Southern Alps extending from the troposphere to the stratosphere in the altitude range between 7.7 and $13.0 \mathrm{~km}$. Wavelet analysis for the $8.9 \mathrm{~km}$ altitude level shows that the enhanced upward water vapor transport above the mountains is caused by mountain waves with horizontal wavelengths between 22 and $60 \mathrm{~km}$. A downward transport of water vapor with $22 \mathrm{~km}$ wavelength is observed in the lee-side of the mountain ridge. While it is a priori not clear whether the observed fluxes are irreversible, low Richardson numbers derived from dropsonde data indicate enhanced turbulence in the tropopause region related to the mountain wave event. Together with the analysis of the water vapor to ozone correlation, we find indications for vertical transport followed by irreversible mixing of water vapor.
\end{abstract}

For our case study, we further estimate greater than $1 \mathrm{~W} \mathrm{~m}^{-2}$ radiative forcing by the increased water vapor concentrations in the UTLS above the Southern Alps of New Zealand, resulting from mountain waves relative to unperturbed conditions. Hence, mountain waves have a great potential to affect the water vapor distribution in the UTLS. Our regional study may motivate further investigations of the global effects of mountain waves on the UTLS water vapor distributions and its radiative effects.

\section{Introduction}

Water vapor is a major greenhouse gas in the upper troposphere-lower stratosphere (UTLS; Sherwood et al., 2010; Solomon et al., 2010). Thus, changes in the water vapor distribution in the UTLS cause radiative forcing and may affect surface temperatures (Solomon et al., 2010; Riese et al., 2012). Therefore, understanding of sources and sinks as well as transport and mixing of water vapor (Holton et al., 1995; Gettelman et al., 2011) is fundamental to quantifying its impact on the atmospheric radiation budget.

There are a few studies that refer to trace gas transport induced by gravity waves (e.g., Danielsen et al., 1991; Langford et al., 1996; Schilling et al., 1999; Moustaoui et al., 2010). Gravity waves are known to play an important role in the circulation, structure and variability of the atmosphere (Fritts and Alexander, 2003). They distribute energy and momentum horizontally and vertically in the atmosphere (e.g., Smith et al., 2008; Geller et al., 2013; Wright et al., 2016). 
The vertical displacement of an air parcel by gravity waves creates fluctuations in trace gas concentrations at constant altitude if the trace gas distribution has a vertical gradient (Smith et al., 2008). For adiabatic processes, tracer mixing ratios as well as the potential temperature are thereby conserved. With respect to an analysis of an adiabatic process, water vapor may serve as an excellent tracer for gravity waves in the troposphere to the lower stratosphere region, while ozone, for example, is a good tracer for the stratosphere. Previous studies investigated the effects of gravity waves on the ozone or carbon monoxide distribution (e.g., Langford et al., 1996; Teitelbaum et al., 1996; Schilling et al., 1999; Moustaoui et al., 2010), while the effects on water vapor are less discussed due to the complex interaction of sources and sinks of water vapor in the UTLS region, for example the possibility of condensation (Moustaoui et al., 1999; Pavelin et al., 2002). Schilling et al. (1999) measured strong fluctuations in $\mathrm{CO}$ mixing ratios at a constant flight level $(11.9 \mathrm{~km})$ caused by mountain waves and calculated the vertical trace gas flux at this altitude. They derived an upward transport of $\mathrm{CO}$ that resulted in enhanced $\mathrm{CO}$ mixing ratios at a higher altitude $(12.5 \mathrm{~km})$. They speculated that dynamic instabilities were induced by wave breaking and that convective overturning finally led to an irreversible vertical $\mathrm{CO}$ transport.

The method to calculate the vertical trace gas flux (Shapiro, 1980; Schilling et al., 1999) is similar to the calculations of energy and momentum fluxes (e.g., by Smith et al., 2008) and indicates the vertical transport direction of the trace gas. If we assume a negative gradient for the trace gas, a positive flux generally will indicate an upward transport of high mixing ratios into a region with low mixing ratios. However, it may also display a downward transport from a region of low mixing ratios to a region with higher mixing ratios (e.g., by existence of an inversion layer). The transport of trace gas species may be reversible or irreversible, depending on processes occurring on different scales. Irreversible mixing is promoted by turbulence induced, for example, by nonlinear wave interaction, wave breaking, or dissipation (Lamarque et al., 1996; Whiteway et al., 2003; Koch et al., 2005; Lane and Sharman, 2006). Danielsen et al. (1991) showed that waves with large horizontal wavelengths ( $\sim 36-$ $270 \mathrm{~km}$ ) and enhanced vertical amplitudes are significant carriers of energy, momentum and trace species. Small-scale waves (horizontal wavelength smaller than $30 \mathrm{~km}$ ) may cause mixing and thus enable the irreversibility of the transport induced by large-scale waves. In a later study, Moustaoui et al. (2010) showed that small-scale waves can also be effective in transport based on reversible dynamic processes.

One method to investigate mixing of trace gases in the UTLS region is to consider the correlation between a tropospheric and a stratospheric tracer (e.g., Fischer et al., 2000; Hoor et al., 2002, 2004; Pan et al., 2007). In an idealized non-mixed atmosphere, a tropospheric tracer (e.g., $\mathrm{H}_{2} \mathrm{O}$ ) and a stratospheric tracer (e.g., $\mathrm{O}_{3}$ ) are not correlated and show an "L shape" in a two-dimensional tracer-tracer plot. Mixing processes across the tropopause (for example by troposphere-stratosphere transport related to tropopause folds or convection) can lead to linear relations (mixing lines) between the tracers. This feature is observed only for irreversible transport. The strength of the mixing and thus the slope of the mixing line is a function of the tracer distributions in the initial air mass and the elapsed time since the mixing took place (Hoor et al., 2002). In addition to transport and mixing processes, in cloudy situations, the tracer-tracer correlations for water vapor may additionally be affected by microphysical processes and cloud formation. In such situations, effects of clouds on the correlations have to be discussed. The consequences of condensation in the tropopause region are not completely displayed in such a correlation plot.

The objective of this paper is to investigate transport of water vapor during a strong mountain wave event using a new combination of different techniques common in gravity wave and atmospheric transport analysis. While previous studies focused on single altitudes, we use measurements in the altitude range between 7.7 and $13.0 \mathrm{~km}$ to cover the upper troposphere and lower stratosphere, including the tropopause region. In contrast to previous studies, which mainly applied simulations (Schilling et al., 1999; Moustaoui et al., 2010), here we investigate the irreversibility of the water vapor transport by using in situ information from tracer-tracer correlations and vertical dropsonde profiles. Furthermore, we are interested in a possible impact of the water vapor distribution in the UTLS on the radiation budget based on radiative transfer calculations by Riese et al. (2012).

To this end, we analyzed measurements from three research flights of the DLR Falcon 20E and the NSF/NCAR Gulfstream V (GV) research aircraft during the DEEPWAVE (Deep Propagating Gravity Wave Experiment) campaign in June-July 2014 above New Zealand (Fritts et al., 2016). The campaign focused on a better understanding of the life cycle of gravity waves from excitation and propagation to dissipation at high altitudes. For the first time, DEEPWAVE combined ground-based and airborne measurements as well as satellite observations over New Zealand and the South Pacific - a "hotspot" region for gravity waves during the southern hemispheric winter. Here, we show results from measurements on 4 July 2014 taken during a strong mountain wave event over the Southern Alps.

First, we describe the in situ measurements on the DLR Falcon and NSF/NCAR GV and the methods to investigate the water vapor transport induced by the mountain waves. Next, we present results for the vertical water vapor flux on a specific flight leg in the upper troposphere. Corresponding wavelet spectra reveal the location and scales of the vertical fluxes. This is followed by a general discussion of the fluxes over a wide altitude range. We then use dropsonde data to identify turbulence layers and investigate tracer-tracer correlations to quantify mixing along the flight tracks over the 
mountains. Finally, we discuss the effects of the mountain waves on the water vapor distribution in the UTLS and on atmospheric radiative transfer.

\section{Instrumentation}

During the DEEPWAVE campaign, the Falcon and the GV were equipped with a set of in situ instruments to determine the trace gas composition and meteorological parameters. Here, we describe the instruments with relevance to this work.

\subsection{Frost point hygrometer on the Falcon}

The gas phase water vapor mixing ratio was determined with the cryogenic frost point hygrometer CR-2 (Buck Research Instruments, LLC) (Voigt et al., 2010, 2011). The instrument measures the temperature of a mirror covered with a thin frost layer that is kept in thermal equilibrium with the ambient water vapor in a closed cell. An optical detector determines the thickness of the frost layer by measuring its reflectivity. The mirror is temperature-regulated so that the condensate layer thickness remains constant. In that state the mirror temperature equals the ambient frost or dew point temperature. Then, the water vapor mixing ratio can be calculated using the inverse Clausius-Clapeyron equation. The instrument covers a wide measurement range between 1 and 20000 ppmv suitable for tropospheric and stratospheric conditions. The sampling time of the CR-2 hygrometer is $0.3 \mathrm{~Hz}$. The data are quality checked by calibrations before and after the campaign against a reference MBW 373LX dew point mirror. During previous campaigns (Voigt et al., 2010, 2014), the instrument agreed well (within $\pm 10 \%$ ) with highaccuracy water vapor data measured with the airborne mass spectrometer AIMS- $\mathrm{H}_{2} \mathrm{O}$ (Kaufmann et al., 2014, 2016). For this campaign, an additional correction for low water vapor mixing ratios has been derived from simultaneous water vapor measurements on the GV research aircraft. The uncertainty of the water vapor mixing ratios is determined by systematic errors in the temperature measurements of the mirror and by the calibration accuracy. The uncertainty is 9 to $12 \%$ for water vapor mixing ratios between 10 and 500 ppmv (Table 1). In the troposphere, the response time of the CR-2 to sudden changes in the mixing ratio is on the order of one to a few seconds. In the stratosphere, the absolute change in water vapor mixing ratios is smaller but the response time can be longer because the time to equilibrate the mirror temperature is longer for low mixing ratios. Therefore, the amplitudes in the CR-2 water vapor measurements in the stratosphere $(<10$ ppmv) may be damped and thus these data are not used quantitatively in this study.
Table 1. Measurement range, accuracy and precision for the CR-2 hygrometer.

\begin{tabular}{lrr}
\hline Measurement range & Accuracy & Precision \\
\hline $50-500 \mathrm{ppmv}$ & $9 \%$ & $1 \%$ \\
$10-50 \mathrm{ppmv}$ & $9-12 \%$ & $2 \%$ \\
$<10 \mathrm{ppmv}$ & $>12 \%$ & $>2 \%$ \\
\hline
\end{tabular}

\subsection{Ozone measurements on the Falcon}

Ozone was measured by an ultraviolet (UV) photometric gas analyzer TE49 (Thermo Environmental Instruments, Inc.) (Schumann et al., 2011; Huntrieser et al., 2016). The absorbance at the wavelength of $254 \mathrm{~nm}$ is directly related to the ozone concentration by the Beer-Lambert law. The sampled air is split into two gas streams which flow to separate optical measurement cells. The gas in one cell serves as reference after ozone is removed by a scrubber. The two cells allow for a simultaneous measurement of both gas streams. The flow to the cells is alternated every $4 \mathrm{~s}$ using a solenoid valve. The response time is $15 \mathrm{~s}$ with a lag time of $10 \mathrm{~s}$. The precision and accuracy are $1 \mathrm{ppbv}$ and $\pm 5 \%$, respectively.

\subsection{Meteorological parameters on the Falcon}

The DLR Falcon aircraft carried a basic meteorological instrumentation suite (Krautstrunk and Giez, 2012). Sensors for pressure and airflow parameters are located on a noseboom in order to minimize the aircraft aerodynamic influence on the ambient air measurement. Total air temperature (TAT) was determined using an open wire PT100 sensor located at the bottom fuselage in the front. To obtain the true static air temperature the measured TAT has to be corrected using the Mach-number-dependent correction factor. The measurement uncertainty is $\pm 0.5 \mathrm{~K}$. The three-dimensional wind speed is calculated from the difference of the ground speed and the true air speed (Mallaun et al., 2015). The prior information comes from the inertial reference system and the latter is measured with a boom-mounted Rosemount 5-hole gust probe. For the horizontal wind components the measurement uncertainties are $\pm 0.7 \mathrm{~m} \mathrm{~s}^{-1}$ (along wind component) and $\pm 0.9 \mathrm{~m} \mathrm{~s}^{-1}$ (cross wind component) and for vertical wind $\pm 0.3 \mathrm{~m} \mathrm{~s}^{-1}$. An onboard GPS system is used to determine the geometric altitude while the pressure height is measured by the static pressure sensor of the 5-hole gust probe. For our analysis we use $1 \mathrm{~Hz}$ averages of the measurement data.

\subsection{The laser hygrometer and dropsonde measurements on the $\mathbf{G V}$}

The NSF/NCAR GV aircraft was also equipped with instrumentation to obtain the meteorological parameters at $1 \mathrm{~Hz}$ time rate (Fritts et al., 2016; Smith et al., 2016). Water va- 
por measurements were made by an open-path vertical cavity surface emitting laser hygrometer (VCSEL, Southwest Sciences, Inc.) (Zondlo et al., 2010). The instrument was installed on the bottom fuselage of the aircraft. Two water vapor absorption lines are used to cover a wide measurement range of high mixing ratios $(1853.3 \mathrm{~nm})$ and moderate to low mixing ratios $(1854.0 \mathrm{~nm})$. The uncertainty is $\pm 5 \%$ at a sampling rate of $25 \mathrm{~Hz}$.

On 4 July, 16 dropsondes were launched by a fully automated Airborne Vertical Atmospheric Profiling System (AVAPS) (Young et al., 2014). The dropsondes (Vaisala, Inc.) contain sensors to measure atmospheric temperature, pressure and humidity and a GPS receiver to derive winds. The data were stored at $2 \mathrm{~Hz}$ which provides a vertical resolution of less than $10 \mathrm{~m}$ in the atmosphere. The uncertainties for the temperature are $\pm 0.2 \mathrm{~K}$ and for the horizontal winds $\pm 0.5 \mathrm{~m} \mathrm{~s}^{-1}$.

\section{Methods}

We present a novel combination of methods to analyze trace gas transport induced by mountain waves. First, we calculate the vertical water vapor flux $\overline{w^{\prime} q^{\prime}}$ in the measurement region as a general transport parameter correlated to the vertical wind motion. Further, the wavelet analysis of $\overline{w^{\prime} q^{\prime}}$ reveals the location, the wavelength and the direction of the vertical trace gas transport. Generally, the method can be applied to any conservative tracer with a gradient in the troposphere and/or the stratosphere. Thus, we apply it in this study to a flight in (nearly) cloud-free conditions. Finally, we investigate the reversibility of the transport using dropsonde data and tracer-tracer correlations.

\subsection{Choice of case study and data preparation}

On 4 July 2014, two flights were performed with the DLR Falcon (referred to as flight numbers FF04 and FF05) and one flight with the NSF/NCAR GV (flight number RF16) (Table 2). On that day, classified as intensive observation period (IOP) number 10 of the DEEPWAVE campaign, a strong mountain wave event with the highest vertical wave-induced energy fluxes during the whole campaign occurred (Fritts et al., 2016; Smith et al., 2016).

During IOP 10 a south-westerly and west-south-westerly flow over the South Island of New Zealand reached more than $40 \mathrm{~m} \mathrm{~s}^{-1}$ (Fig. 1a). The flight pattern of the DLR Falcon (Fig. 1) was chosen to be nearly parallel to the main wind direction over the Southern Alps, with Mount Aspiring as the highest summit. The flight legs above the mountains were flown 4 times during each Falcon flight to cover different altitudes and to determine the mountain wave situation below and above the tropopause. For the analysis, we define cross sections covering the whole mountain range at each altitude with neither an altitude change nor a turn of the aircraft. Mount Aspiring $\left(44.38^{\circ} \mathrm{S}, 168.73^{\circ} \mathrm{E}\right)$ was defined as the reference point for each flight leg (red triangle in Fig. 1) and the distance to this reference point is used as $x$-axis scaling for the analysis.

In this study, we use all data in a $1 \mathrm{~Hz}$ time resolution. Therefore, we interpolated the lower frequency measurements to a $1 \mathrm{~s}$ time grid as consistent data input for a subsequent wavelet analysis. A sensitivity analysis using the coarser time resolution of the CR-2 $(0.3 \mathrm{~Hz})$ as a base for the evaluation did not change the results. Since we are not looking at this point into the turbulent part of the wavelength spectrum, the $1 \mathrm{~s}$ interpolation is sufficient.

\subsection{Method to calculate the vertical water vapor flux}

The calculation of a vertical trace gas flux was first described by Shapiro (1980). The basic assumption of this method is that we consider a conservative and passive tracer $q$ without sources and sinks such that

$\frac{\mathrm{d} q}{\mathrm{~d} t}=\frac{\partial q}{\partial t}+\boldsymbol{v} \cdot \operatorname{div}(\boldsymbol{q})=0$,

where $t$ is the time, $v$ is the vector field of the horizontal and vertical wind components $u, v$ and $w$, and $\operatorname{div}(\boldsymbol{q})$ is the divergence of the passive tracer. Since there were no clouds over the mountain transect for the analyzed altitudes, water vapor is a conservative tracer in our case and its distribution is not influenced by condensation or sublimation.

The quantity $q$ as well as the wind components may be expressed in terms of a spatial (x) or temporal mean $\bar{q}$ and perturbations $q^{\prime}$ :

$q(x)=\bar{q}+q^{\prime}(x)$.

Under the assumption that we can neglect the mean horizontal and vertical advection of $\bar{q}$ in the measurement region, we consider the local temporal change of $\bar{q}$ as follows:

$\frac{\partial \bar{q}}{\partial t}=-\frac{\partial}{\partial x}\left(\overline{u^{\prime} q^{\prime}}\right)-\frac{\partial}{\partial y}\left(\overline{v^{\prime} q^{\prime}}\right)-\frac{\partial}{\partial z}\left(\overline{w^{\prime} q^{\prime}}\right)$,

where $u^{\prime}$ and $v^{\prime}$ are the horizontal wind perturbations and $w^{\prime}$ is the vertical wind perturbation. The overlines mark the mean trace gas flux over spatial or temporal intervals. Furthermore, we assume that the horizontal flux divergences are negligible compared to the vertical flux divergence and hence Eq. (3) reduces to

$\frac{\partial \bar{q}}{\partial t}=-\frac{\partial}{\partial z}\left(\overline{w^{\prime} q^{\prime}}\right)$.

The local vertical trace gas flux is then determined by

$w^{\prime} q^{\prime}(x)=q^{\prime}(x) \cdot w^{\prime}(x)$,

where the perturbations depends on the filter function used to receive the spatial mean:

$\bar{q}=\frac{1}{x_{2}-x_{1}} \cdot \int_{x_{1}}^{x_{2}} q(x) \mathrm{d} x$. 
Table 2. Overview of the research flights on 4 July 2014 (FF = Falcon research flight, $\mathrm{RF}=\mathrm{GV}$ research flight).

\begin{tabular}{llll}
\hline Aircraft & Flight no. & Flight time (UTC) & Dropsonde launches \\
\hline DLR Falcon 20E & FF04 & $02: 46-06: 09$ & - \\
DLR Falcon 20E & FF05 & $07: 23-11: 00$ & - \\
NSF/NCAR Gulfstream V & RF16 & $05: 59-12: 55$ & 15 (mountain transect); \\
& & & 1 (east of South Island) \\
\hline
\end{tabular}
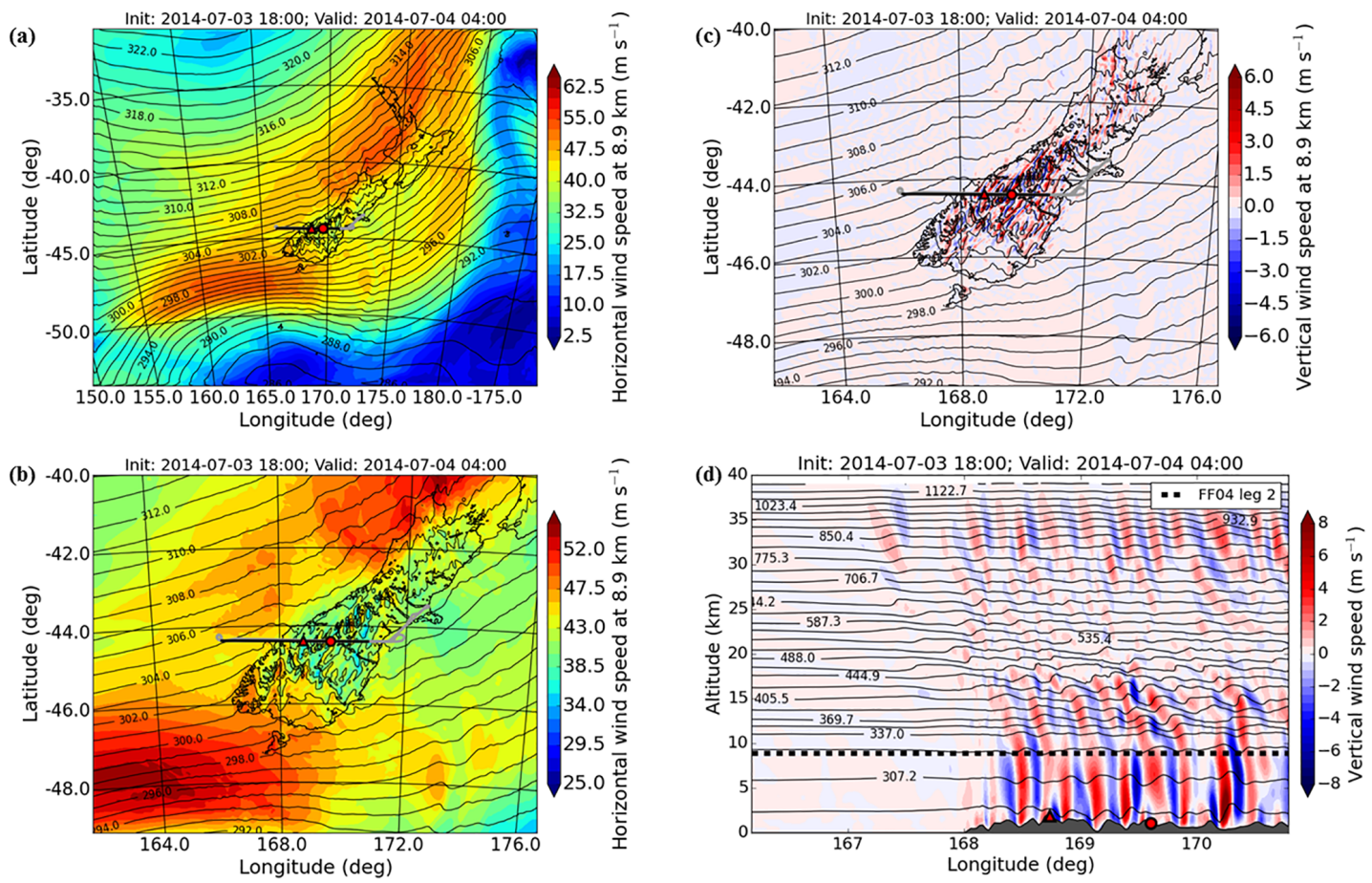

Figure 1. Synoptic situation on 4 July 2014 at 04:00 UTC simulated by WRF: (a) horizontal wind speed at 8.9 km (altitude of DLR Falcon flight FF04 leg 2) for New Zealand, (b) horizontal wind speed over the South Island of New Zealand (zoom of a), (c) vertical wind speed at $8.9 \mathrm{~km}$ over the South Island of New Zealand and (d) cross section of the vertical wind speed along the flight leg. Contour lines represent the potential temperature at $8.9 \mathrm{~km}(\mathbf{a}-\mathbf{c})$ and over the altitude (d). The thick black line in (a)-(c) displays the cross-mountain flight path and the grey line shows the whole flight path of the DLR Falcon flight FF04. The thick black dashed line in (d) indicates the altitude of the second flight leg of FF04 and the grey area at the bottom displays the topography. The red dot in all panels marks the position of the dropsonde launch from the GV at 08:00 UTC (see Fig. 7) and the red triangle marks the position of Mount Aspiring.

We derive the mean vertical trace gas flux $\overline{w^{\prime} q^{\prime}}$ from integrating over selected spatial or temporal intervals along the mountain cross section (see Sect. 4.4). For an ideal linear wave, the mean vertical flux would be zero. If we observe a negative or positive mean flux, a trace gas transport will exist but we need further analysis on the irreversibility of the transport process.

The filter function and its characteristics have an important influence on the results. We have to decide which scales of horizontal wavelength to include and which parts of the spectrum to neglect. In this study, the length of the flight legs limits the maximum resolvable horizontal wavelength to less than $150 \mathrm{~km}$. In addition, a change in the wind direction in front of the mountains partially influences the water vapor distribution at wavelengths larger than $80 \mathrm{~km}$. Therefore, a suitable filter choice in our case is a band-pass filter with a lower limit of $300 \mathrm{~m}$ and an upper limit of $80 \mathrm{~km}$. It must be kept in mind that the band-pass filter as spatial filter method may damp wavelengths due to edge effects (Ehard et al., 2015). We apply the filter to the water vapor measurements as well as to the vertical wind measurements.

\subsection{Wavelet analysis method}

Wavelet analysis is widely used in gravity wave analysis to identify the location and wavelength scale of waves (e.g., Woods and Smith, 2010; Placke et al., 2013; Zhang et al., 2015). By combining power spectra and cospectra of the variables of interest, flux carrying waves can be characterized. 
We calculated normalized power spectra of the vertical wind and the water vapor perturbation using the Morlet wavelet as defined in Torrence and Compo (1998) and an equalized distance of $200 \mathrm{~m}$ between each data point. For the calculation we create standard normally distributed perturbed variables $q^{\prime}$ and $w^{\prime}$.

The cospectrum $W_{n}^{X Y}(s)$ of the vertical trace gas flux $w^{\prime} q^{\prime}$ combines the real parts of the wavelet spectra of both variables:

$W_{n}^{X Y}(s)=\operatorname{Re}\left\{W_{n}^{X}(s) W_{n}^{Y *}(s)\right\}$,

where $X$ and $Y$ represent the variables $w$ and $q, n$ classifies the localized position index, $s$ is the wavelet scale and $*$ is the complex conjugate. This results in the in-phase contributions to a product from different wavelengths. The significance is determined with the method from Portele et al. (2017) as follows:

$$
\frac{\left|W_{n}^{X}(s) W_{n}^{Y *}(s)\right|}{\sqrt{\left|P_{k}^{X} P_{k}^{Y}\right|}}=\frac{\chi_{v}^{2}(p)}{v},
$$

where $P_{k}$ represents the normalized Markov red noise spectrum with the frequency index $k=0 \ldots N-1$ with $N$ as the number of points in the data series, $\chi_{v}^{2}$ is the chi-square distribution for $v$ degrees of freedom and $p$ is the significance. For this case we use in Eq. (8),

$$
P_{k}=\frac{1-\alpha^{2}}{1+\alpha^{2}-1 \alpha \cos (2 \pi k / N)},
$$

a combined autocorrelation factor $\alpha$ with a lag of 1 and a lag of $10(\alpha=\operatorname{lag} 1+\sqrt{\operatorname{lag} 10} / 2)$. The original time series is correlated with a delayed copy of itself (time lag) to obtain the significant parts of the cospectrum. The chosen combination includes signals of larger wavelengths (significant for high time lags) and smaller wavelengths (significant for lower lags) without stressing any of them (Portele et al., 2017).

\section{Results}

First, we show the results of the flux calculations and wavelet analysis for one selected flight altitude. Then, we discuss the water vapor measurements on different flight altitudes to characterize the vertical flux from the upper troposphere to the lower stratosphere. Finally, we use dropsonde data to identify regions with enhanced turbulence and with a vertical gradient of the potential temperature close to zero. Additionally, we investigate mixing processes in the measurement region using tracer-tracer correlations, in this case of water vapor and ozone.

\subsection{Synoptic situation on 4 July 2014}

Mesoscale simulations with the Weather Research and Forecasting (WRF) model, version 3.7 (Skamarock et al., 2008), were performed to give an overview of the synoptic situation. Two nested domains with horizontal resolutions of 6 and $2 \mathrm{~km}$ and 138 vertical levels with a model top at $2 \mathrm{hPa}$ were used. The model is initialized with operational analyses of the ECMWF model at 18:00 UTC on 3 July 2014 and run for $36 \mathrm{~h}$. A detailed overview of the same model set-up including the parameterizations used can be found in Ehard et al. (2016) for a gravity wave event over northern Scandinavia.

For 4 July 2014 the orographic forcing over the Southern Alps was induced by a south-westerly wind of $\sim 20 \mathrm{~m} \mathrm{~s}^{-1}$ at $850 \mathrm{hPa}$ at the west coast of the South Island of New Zealand (not shown). Up to the tropospheric jet level around $8.9 \mathrm{~km}$ (at $300 \mathrm{hPa}$ ), horizontal wind speeds in the upstream region accelerate up to $50 \mathrm{~m} \mathrm{~s}^{-1}$ (Fig. 1a). Over the mountains the horizontal wind velocities decreased to 30 to $40 \mathrm{~m} \mathrm{~s}^{-1}$ (Fig. 1b) and changed from a westerly direction west of the South Island to south-westerly. A part of the core region of the tropospheric jet was located west of the South Island (Fig. 1b). The strong low-level flow forced mountain waves, as clearly indicated by the vertical wind speed values over the island at $8.9 \mathrm{~km}$ altitude (Fig. 1c). The mountain waves are excited in the lower troposphere and propagate vertically through the tropopause region and lower stratosphere (Fig. 1d).

The intensity of the mountain wave forcing over New Zealand on 4 July 2014 changed within several hours. The forcing at the west edge of the mountains was strongest at 06:00 UTC and weakened until 18:00 UTC. Also, a lowpressure system south of New Zealand moved quickly eastward and led to a thermal tropopause (WMO, 1957), descending from $11.1 \mathrm{~km}$ to $9.5 \mathrm{~km}$ during the observation period. A detailed overview of the synoptic situation for 4 July 2014 is given by Bramberger et al. (2017).

\subsection{Vertical water vapor flux at $8.9 \mathrm{~km}$}

An overview of the first Falcon flight, FF04, on 4 July 2014 is shown in Fig. 2. We identify strong fluctuations in water vapor, potential temperature and horizontal and vertical wind components at different altitudes during the flight. In particular, the vertical wind component varied $\pm 5 \mathrm{~m} \mathrm{~s}^{-1}$ over the mountains (bottom panel). For water vapor we detect the strongest perturbations in the same region over the mountains during the first and second flight leg $(7.7$ and $8.9 \mathrm{~km})$ with amplitudes of up to $100 \mathrm{ppmv}$. The amplitudes decrease with altitude due to the general decline of the $\mathrm{H}_{2} \mathrm{O}$ concentrations in the UTLS. Ozone shows strong variations over the mountains in the stratosphere and less variability in the troposphere, opposite to the $\mathrm{H}_{2} \mathrm{O}$ signal. Also, the potential temperature as well as the horizontal wind components displays fluctuations above the mountains. The location and extent of the fluctuations imply mountain waves as a source, as suggested by studies from Smith et al. (2016) and Bramberger et al. (2017). 


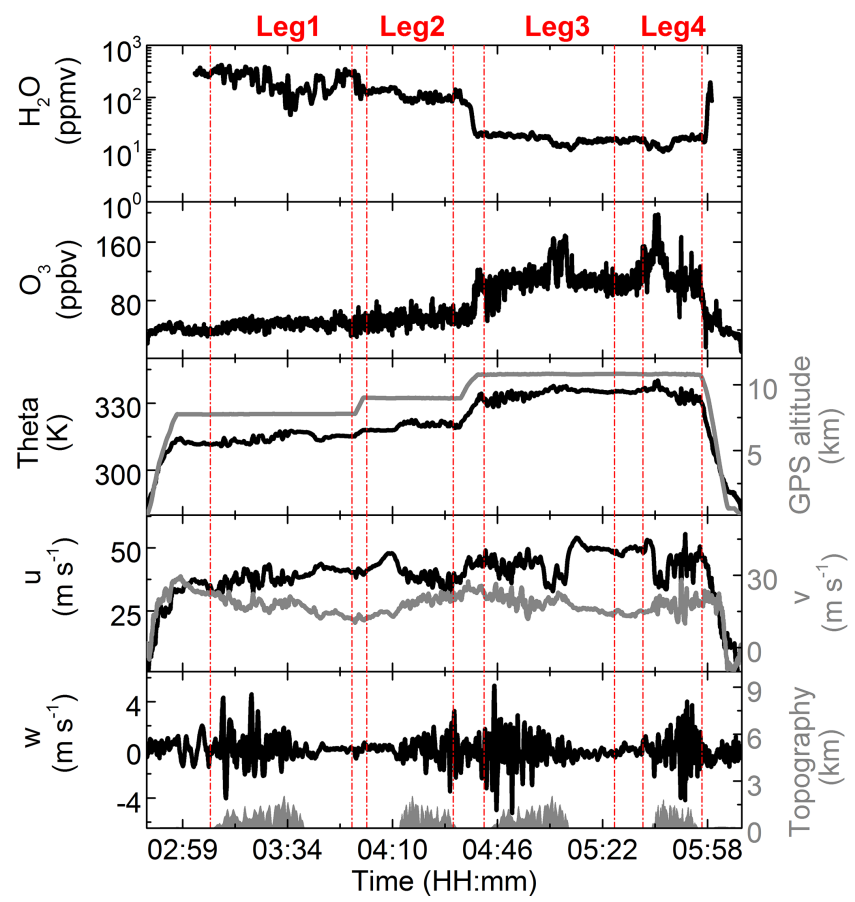

Figure 2. DLR Falcon flight FF04 on 4 July 2014 above the Southern Alps: time series of observations during the mountain wave event. Water vapor mixing ratio (from CR-2), ozone mixing ratio, potential temperature and flight altitude (grey) as well as zonal wind, meridional wind (grey), vertical wind and topography (grey area at the bottom) are shown. Flight legs are separated by dashed red lines.

For this work we chose the second flight leg at $8.9 \mathrm{~km}$ as an example to analyze the water vapor transport (Fig. 3). In the upper troposphere the water vapor measurements with the CR-2 hygrometer are very sensitive to sudden changes in the mixing ratio, such as those caused by mountain waves. The flight leg is located in the upper troposphere with a distance of approximately $2 \mathrm{~km}$ to the thermal tropopause at $10.9 \mathrm{~km}$. The wave signature in water vapor is very distinctive, with high amplitudes of 20 ppmv above the Mount Aspiring transect. The potential temperature shows a similar wave pattern to water vapor but is anti-correlated (selected instances indicated by vertical blue dashed lines in Fig. 3) and follows the vertical wind fluctuations. Additionally, there is a slow decrease in the water vapor mixing ratio from $-80 \mathrm{~km}$ distance to the summit at $x=0 \mathrm{~km}$, along with an increase in the potential temperature of $3 \mathrm{~K}$ and a change in the wind direction. The upstream region of the transect is located in the vicinity of the tropospheric jet stream, which may influence the upstream water vapor distribution by horizontal largerscale processes.

Results from the flux calculations for this flight leg are displayed in Fig. 4. We applied the band-pass filter with an upper limit of $80 \mathrm{~km}$ wavelength to the water vapor and the vertical wind data and show the received perturbations $w^{\prime}$ and

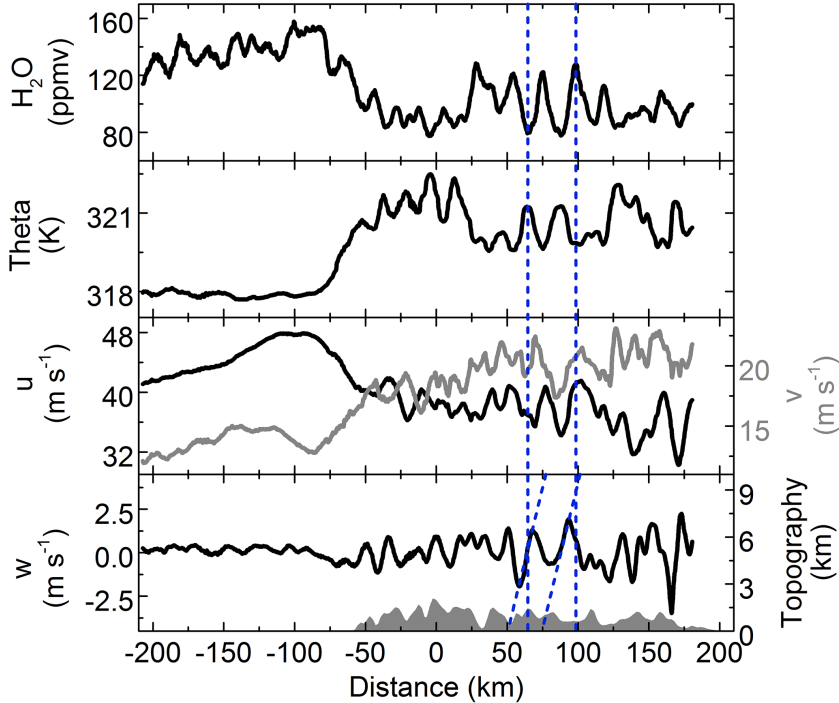

Figure 3. A portion of the time series of the DLR Falcon flight FF04 on 4 July 2014 shown in Fig. 2. The measurements were taken during the second flight leg at $8.9 \mathrm{~km}$ altitude over the South Island of New Zealand. The distance refers to Mount Aspiring as the highest summit during this mountain transect (west to east). The vertical blue dashed lines mark single wave events. The diagonal blue dashed lines in the bottom panel connect the maximum or minimum of the vertical wind motion with the respective maximum or minimum in the perturbations of water vapor and theta which displays the phase shift between these parameters.

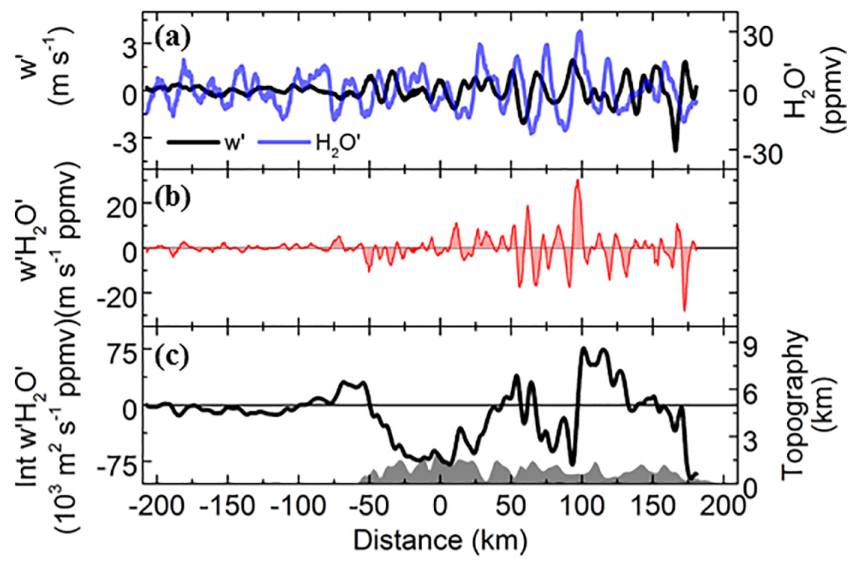

Figure 4. Same flight leg as in Fig. 3. Shown are components of the vertical water vapor flux. The vertical wind perturbation (black) and the water vapor perturbation (blue) in (a) are combined to the local vertical water vapor flux $w^{\prime} \mathrm{H}_{2} \mathrm{O}^{\prime}$ (b). The bottom panel (c) shows the integrated vertical water vapor flux $\int w^{\prime} \mathrm{H}_{2} \mathrm{O}^{\prime} \mathrm{d} x$ and the topography.

$\mathrm{H}_{2} \mathrm{O}^{\prime}$ in panel (a). The two variables are $90^{\circ}$ phase shifted with respect to each other, which can also be observed by the diagonal blue dashed lines in the bottom panel of Fig. 3. This phase shift is caused by a direct response of water vapor to 
the vertical wind motion. We assume an atmosphere finely layered with conserved quantities. These layers are disturbed by propagating gravity waves, and an aircraft flying at a constant level penetrates the layers repeatedly, as depicted in Fig. 10 of Smith et al. (2008). At a constant altitude, therefore, the trace gas concentration and potential temperature follow the vertical wind variations with a phase shift of $90^{\circ}$.

A strong wave signature is detected in the local vertical water vapor flux $w^{\prime} \mathrm{H}_{2} \mathrm{O}^{\prime}$ above the mountains (Fig. 4b). The vertical flux is very small in the upstream region and the amplitude increases over the mountains from west to east. Figure $4 \mathrm{c}$ shows the integrated vertical water vapor flux. It is generally increasing above the mountains between +30 and $+60 \mathrm{~km}$ and from +90 to $+180 \mathrm{~km}$ distance to the Mount Aspiring summit, with a maximum of 39000 and $76000 \mathrm{~m}^{2} \mathrm{~s}^{-1} \mathrm{ppmv}$, respectively. Further east we find a negative trend $\left(-98000 \mathrm{~m}^{2} \mathrm{~s}^{-1} \mathrm{ppmv}\right)$ induced by small water vapor perturbations but enhanced vertical wind fluctuations. At the western edge of the mountains (between -50 and $+30 \mathrm{~km}$ ) we also observe a negative flux. This region is located in the vicinity of the tropospheric jet stream which influences the distribution of the water vapor mixing ratio by horizontal transport processes (Fig. 3: decrease of $\mathrm{H}_{2} \mathrm{O}$ from west to east between -80 and $0 \mathrm{~km}$ distance). This behavior cannot fully be eliminated by the used filter and is thus present in the water vapor perturbations by a few fluctuations with a negative weighting.

Since water vapor has a negative gradient in the troposphere, a positive flux mainly indicates upward transport of high mixing ratios to a level of lower mixing ratio. A negative flux points to a downward transport. Thus, we find a strong indication of an integrated upward water vapor flux above the Southern Alps and a downward flux above the eastern part of the mountains for this flight leg.

For the flux calculations we used water vapor as conservative tracer due to the absence of supersaturation at the analyzed flight altitudes. However, at the first flight leg of FF04 at $7.7 \mathrm{~km}$ we measured ice particles with the in situ instrumentation, with a detection limit for the ice water content of 0.2 ppmv. The cloud was detected between +150 and $+200 \mathrm{~km}$ distance and indicates the existence of a lee wave cirrus. This gravity-wave-induced cloud was also visible in the infrared images of the MTSAT-2 satellite at 03:00 UTC and dissipated until 06:00 UTC (Bramberger et al., 2017). No further clouds were measured on the other flight legs and in particular not during those legs for which the flux calculations were performed. However, the presence of an ice cloud on a lower layer may affect the water vapor distribution at a higher flight level $(8.9 \mathrm{~km})$ by lowering the amplitude of the fluctuation. In Fig. 3 we observe a strong negative peak in the vertical wind at $+170 \mathrm{~km}$ distance to the summit in contrast to a small water vapor fluctuation which may be influenced by the drying of the level below. The calculated flux in this region is then also reduced. This effect does not influence the general transport direction at this flight altitude and is not
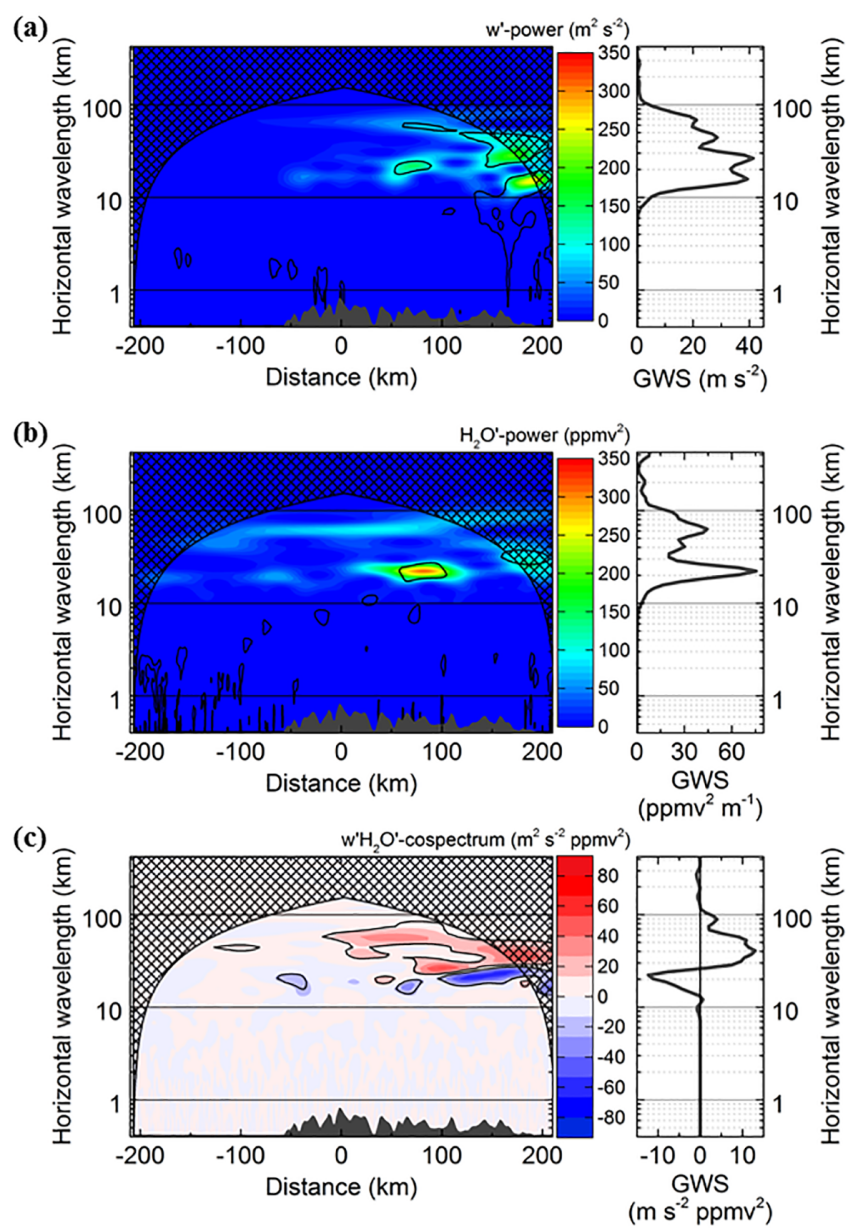

Figure 5. Wavelet analysis of the second flight leg of the DLR Falcon flight FF04 shown in Fig. 2: (a) power spectrum of vertical wind perturbation $w^{\prime}$, (b) power spectrum of water vapor perturbation $\mathrm{H}_{2} \mathrm{O}^{\prime}$ and (c) cospectrum of the vertical water vapor flux $w^{\prime} \mathrm{H}_{2} \mathrm{O}^{\prime}$. The right panels show the corresponding global wavelet spectrum (GWS). Thin black lines around colored areas are the $95 \%$ confidence level; the crosshatched area is the COI. The topography (maximum mountain height of $2049 \mathrm{~m}$ ) is represented by the dark grey area in the bottom of each panel.

relevant for the higher flight altitudes or the second Falcon flight since these lee wave clouds were not observed above $7.7 \mathrm{~km}$ and dissipated during the first flight.

\subsection{Wavelength spectrum of the vertical water vapor flux}

Wavelet analysis is used to quantify location, scale and direction of the vertical water vapor flux. Figure 5 shows the amplitudes of perturbations in vertical wind (a) and water vapor (b) for the second flight leg of FF04 for horizontal wavelengths between $300 \mathrm{~m}$ and $400 \mathrm{~km}$. The power spectra represent the variance wavelets for $w^{\prime}$ and $\mathrm{H}_{2} \mathrm{O}^{\prime}$ while the cospectrum shows the covariance wavelet for $w^{\prime} \mathrm{H}_{2} \mathrm{O}^{\prime}$. The highest activity in both variables occurs for wavelengths be- 
tween 10 and $80 \mathrm{~km}$, where the upper limit results from the band-pass filter. Moreover, the peaks are located above the middle and eastern part of the mountains. We find similar patterns in $w$ and $\mathrm{H}_{2} \mathrm{O}^{\prime}$ but of different intensity. Water vapor has the strongest peak at $+75 \mathrm{~km}$ distance and at $22 \mathrm{~km}$ horizontal wavelength, whereas the intensities of the vertical wind perturbation are strongest further east at $+180 \mathrm{~km}$ from the summit with a broader wavelength range between 15 and $30 \mathrm{~km}$. The power of the water vapor fluctuation in this region may be reduced due to condensation at the flight altitude below, as mentioned before. Since the flight legs are short in the downstream region, data for $x>+200 \mathrm{~km}$ lie in the cone of influence (COI) area and thus require careful interpretation due to edge effects of the analysis (Torrence and Compo, 1998). Additionally, we find a layer of enhanced magnitude in the power of the water vapor perturbations at a wavelength of about $60 \mathrm{~km}$ located at -80 to $+100 \mathrm{~km}$ distance. This may be caused by longer waves that are not part of this analysis and that are influenced by horizontal advection due to the tropospheric jet stream. There are some significant areas in the upstream region, as well as over the eastern part of the mountains in both power spectra for wavelengths larger than $10 \mathrm{~km}$ with amplitudes smaller than $0.1 \mathrm{~m}^{2} \mathrm{~s}^{-2}$ and smaller than $0.1 \mathrm{ppmv}^{2}$, respectively. This indicates additional smallscale fluctuations in the parameters that may not be relevant for transport of water vapor but for mixing processes. These small-scale fluctuations are especially observed for the vertical wind over the middle and eastern mountain region at the higher altitudes (not shown) where we find indications for turbulence in the dropsonde data (see Sect. 5).

In the right panels of Fig. 5, we show the global wavelet spectrum (GWS) where the power is averaged over all local wavelet spectra. This highlights the dominant wavelengths along the flight path. Most power is carried in wavelengths smaller than $30 \mathrm{~km}$ for both variables. A second mode with less power is found between 40 and $80 \mathrm{~km}$ horizontal wavelength.

Figure 5c shows the corresponding cospectrum of $w^{\prime} \mathrm{H}_{2} \mathrm{O}^{\prime}$. As in the individual power spectra, we identify dominant horizontal wavelengths between 10 and $80 \mathrm{~km}$. The location of upward or downward transport is represented in the colorcoding with red areas indicating an upward $\mathrm{H}_{2} \mathrm{O}$ flux and blue the opposite. The significant parts from the individual power spectra contribute to the local flux. Horizontal wavelengths between 22 and $60 \mathrm{~km}$ dominantly contribute to an upward water vapor transport above the mountain region. The downward water vapor flux above the eastern mountain part is mainly carried by wavelengths between 20 and $22 \mathrm{~km}$. The vertical wind perturbation dominantly influences this transport direction. Quadrant analysis of $w$ and $\mathrm{H}_{2} \mathrm{O}^{\prime}$ (not shown) reveal that the positive flux $w^{\prime} \mathrm{H}_{2} \mathrm{O}^{\prime}$ is dominated by the upward transport of high humidity in regions with low humidity for wavelengths larger than $22 \mathrm{~km}$. Less pronounced is the downward transport of low humidity that also causes a positive flux. The negative flux for horizontal wave- lengths smaller than $22 \mathrm{~km}$ is a result of the upward transport of low humidity and the downward transport of high humidity in equal parts, which caused a reduced water vapor mixing ratio in this region.

The results show an overall upward transport of $\mathrm{H}_{2} \mathrm{O}$ at this flight altitude. Further, a superposition of wave packets with different characteristics is detected in the mountain wave region. The rugged terrain of the Southern Alps with many crests and valleys may initiate these different contributions to the full spectrum. In the statistical analysis of all GV flight level data during DEEPWAVE, Smith et al. (2016) also observed small- and longer-scale waves with different characteristics. In their study flux-carrying waves are larger than $20 \mathrm{~km}$ horizontal wavelength. Small-scale waves with wavelengths around $20 \mathrm{~km}$ and less are mainly dominating in the vertical wind motion and do not carry any energy or momentum flux upward (Smith and Kruse, 2017). This is explained by dynamic reasons since only the longer-scale waves that propagate vertically and are not evanescent transport energy and momentum vertically. For water vapor as a passive tracer the reasons for the chosen scale separation are the same in this wavelength range. Transport processes by large-scale waves with horizontal wavelengths larger than $100 \mathrm{~km}$ would presumably be different for energy or momentum and water vapor.

\subsection{Vertical profile of the water vapor flux from the troposphere to the stratosphere}

We combine GV and Falcon data on 4 July 2014 to derive a profile of the vertical water vapor flux in the UTLS region. The Falcon flights FF04 and FF05 covered a temporal evolution of the mountain wave activity that increased from the first to the second flight (Bramberger et al., 2017). The GV operated simultaneously to the second Falcon flight FF05 (Table 2). Both aircraft flew on the same flight track but at different altitudes to measure the vertical propagation of the mountain waves. In Fig. 6a, we show the Falcon flight legs 1 to 3 (FF05) between 7.7 and $10.8 \mathrm{~km}$ and two GV flight legs at 12.0 and $13.0 \mathrm{~km}$ that took place at the same time as leg 3 and leg 4 of FF05. The fourth leg of FF05 is not shown since amplitudes in the water vapor fluctuations cannot be fully resolved by the CR-2 in the stratosphere. During all Falcon and GV transects, we find significant water vapor fluxes over the mountain region (Fig. 6a). The thermal tropopause was located at about $10.5 \mathrm{~km}$, thus the observed water vapor flux extends above the tropopause. The wave pattern remains nearly stationary through all altitudes with, for example, a strong wave package at about $+110 \mathrm{~km}$ distance from the reference point. Upstream and downstream regions exhibit very low or no vertical fluxes.

To derive a vertical profile of the vertical water vapor flux in the mountain wave region, we define a range between the highest summit $(x=0 \mathrm{~km})$ and the east end of the Southern Alps $(x=202 \mathrm{~km})$. For this region, the integrated vertical 

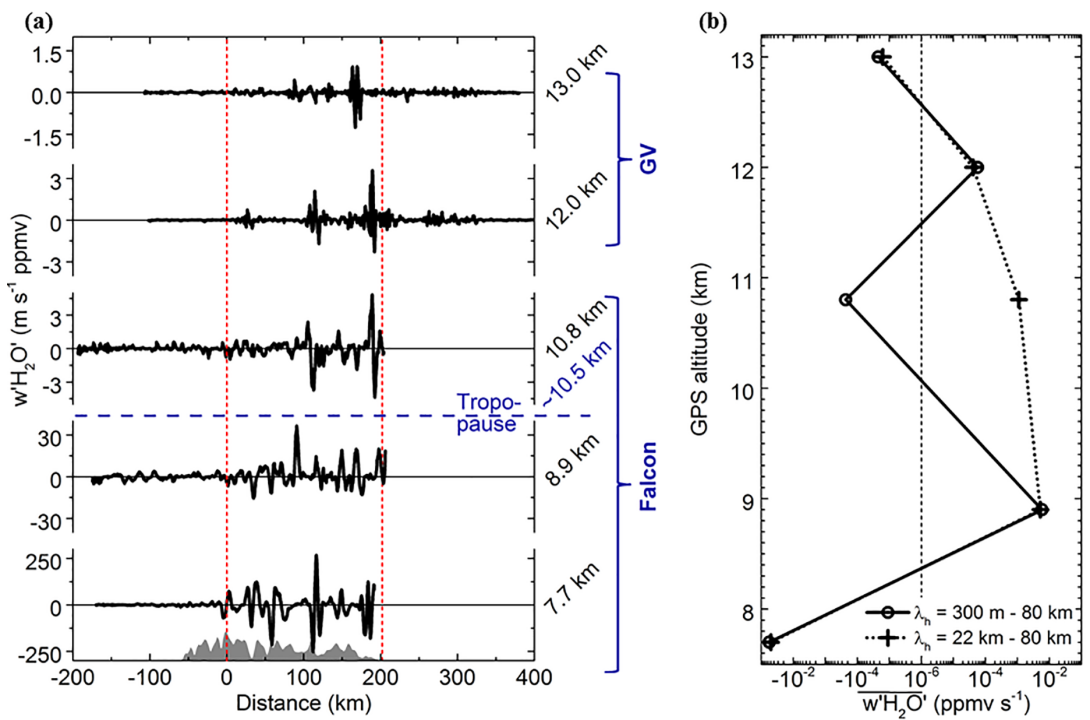

Figure 6. (a) Vertical water vapor fluxes using data from DLR Falcon flight FF05 (lower three panels) and NSF/NCAR GV flight RF16 (upper two panels) on 4 July 2014. The fluxes are shown for different flight altitudes over the topography of the Southern Alps. The approximate height of the tropopause at $10.5 \mathrm{~km}$ is displayed by the dashed blue line. The red dashed lines mark the region that is used to get the water vapor fluxes shown in panel (b). (b) Vertical profile of the water vapor fluxes integrated over the mountain region with the highest mountain wave activity. The profiles are shown for horizontal wavelengths between $300 \mathrm{~m}$ and $80 \mathrm{~km}$ (solid line) and between 22 and $80 \mathrm{~km}$ (dashed line).

water vapor flux is normalized by the length. The results at each altitude are plotted in Fig. 6b. To distinguish the transport characteristics of different horizontal wavelengths, we show the profile for wavelengths between $300 \mathrm{~m}$ and $80 \mathrm{~km}$ and between 22 and $80 \mathrm{~km}$, respectively. Under the assumption of quasi-stationary mountain waves, we neglect the time shift ( $\sim 3 \mathrm{~h}$ ) between the single flight legs.

In general, a negative (positive) flux divergence $\frac{\partial\left(\overline{w^{\prime} \mathrm{H}_{2} \mathrm{O}^{\prime}}\right)}{\partial z}$ humidifies (dries) the layer above due to the negative water vapor gradient in the atmosphere. By the absence of vertical or horizontal transport and the existence of a well-mixed atmosphere, a flux divergence is not expected. In the mountain region we see positive flux divergences in the troposphere $(7.7-8.9 \mathrm{~km})$ and lower stratosphere $(10.8-12.0 \mathrm{~km})$ for horizontal wavelengths between $300 \mathrm{~m}$ and $80 \mathrm{~km}$ (Fig. 6b), which may indicate a general downward transport (Table 3). The strong negative vertical flux at the lowest altitude may be influenced by transport and mixing processes that lie below this level and that are not covered by the in situ measurements. This may be convective processes in front of or over the mountains. The positive flux divergence in the layer from 10.8 to $12 \mathrm{~km}$ implies a drying of the atmosphere by a downward transport. In the layer below, from 8.9 to $10.8 \mathrm{~km}$, a strong upward transport from the upper troposphere through the tropopause occurs, which is indicated by the negative flux divergence. This process may lead to the observed enhanced water vapor mixing ratios at around $10.8 \mathrm{~km}$ and below (see Sect. 6). Since we only have measurements on a few defined altitudes an exact localization of maxima and of sign changes of the transport direction is not possible. For the first Falcon flight we find a similar pattern and values for the flux divergence between 7.7 and $10.8 \mathrm{~km}$ (Table 3). The use of other levels could change the pattern slightly but the general trend appears to be robust. Vertically resolved data (e.g., by lidar measurements) would be required to derive the vertical curtain of the flux divergence but were not performed during this campaign.

The picture changes when excluding the small wavelengths below $22 \mathrm{~km}$ (dashed line in Fig. 6b). We then find a negative flux divergence over the broad altitude range from upper troposphere to lower stratosphere $(8.9-13 \mathrm{~km})$. This indicates a dominating upward transport of water vapor by the larger wavelengths (see Fig. 5c). When comparing both profiles, the difference between them in the layer between 8.9 and $12.0 \mathrm{~km}$ suggests that the positive flux divergence (downward transport) between 10.8 and $12.0 \mathrm{~km}$ is mainly induced by small horizontal wavelengths (Table 3 ). These smaller wavelengths indicate instabilities in the atmosphere and thus the upward mountain wave propagation may be influenced by local turbulence (see Sect. 5) or by downward propagating gravity waves that are excited aloft (Bramberger et al., 2017).

\section{Turbulence in the UTLS region}

Gravity waves may cause or enhance turbulence by instabilities, wave breaking and dissipation (e.g., Pavelin et al., 2002; 
Table 3. Vertical flux divergence of water vapor for the combined research flights FF04, FF05 and RF16. The results are shown for two horizontal wavelength ranges.

\begin{tabular}{|c|c|c|c|c|}
\hline Flight no. & Leg number & Altitude $(\mathrm{km})$ & $\begin{array}{r}\frac{\partial\left(\overline{w^{\prime} \mathrm{H}_{2} \mathrm{O}^{\prime}}\right)}{\partial z}\left(\mathrm{ppmv} \mathrm{s}^{-1}\right) \\
\lambda_{\mathrm{h}}=300 \mathrm{~m}-80 \mathrm{~km}\end{array}$ & $\begin{array}{r}\frac{\partial\left(\overline{w^{\prime} \mathrm{H}_{2} \mathrm{O}^{\prime}}\right)}{\partial z}\left(\mathrm{ppmv} \mathrm{s}^{-1}\right) \\
\lambda_{\mathrm{h}}=22-80 \mathrm{~km}\end{array}$ \\
\hline FF04 & $\operatorname{leg} 1 \rightarrow \operatorname{leg} 2$ & $7.7-8.9$ & $3.0 \times 10^{-2}$ & $-2.9 \times 10^{-2}$ \\
\hline FF04 & $\operatorname{leg} 2 \rightarrow \operatorname{leg} 3$ & $8.9-10.8$ & $-1.5 \times 10^{-3}$ & $-1.1 \times 10^{-3}$ \\
\hline FF05 & $\operatorname{leg} 1 \rightarrow \operatorname{leg} 2$ & $7.7-8.9$ & $5.2 \times 10^{-2}$ & $4.6 \times 10^{-2}$ \\
\hline FF05 & $\operatorname{leg} 2 \rightarrow \operatorname{leg} 3$ & $8.9-10.8$ & $-3.2 \times 10^{-3}$ & $-2.2 \times 10^{-3}$ \\
\hline FF05/RF16 & $\operatorname{leg} 3(\mathrm{FF} 05) \rightarrow \operatorname{leg} 4(\mathrm{RF} 16)$ & $10.8-12.0$ & $2.4 \times 10^{-4}$ & $-9.0 \times 10^{-4}$ \\
\hline RF16 & $\operatorname{leg} 4 \rightarrow \operatorname{leg} 5$ & $12.0-13.0$ & $-7.9 \times 10^{-5}$ & $-5.8 \times 10^{-5}$ \\
\hline
\end{tabular}

Fritts and Alexander, 2003; Whiteway et al., 2003). Here, we use dropsonde launches from the GV to investigate turbulence potentially induced by the mountain waves which may cause mixing of trace species in the measurement region. Therefore, we calculate potential temperature and Richardson numbers $(R i)$ from the data set. In general, a Richardson number below 0.25 indicates an unstable flow that initiates turbulence (Miles, 1961; Howard, 2006). Further, there is evidence that turbulence is maintained for $R i$ smaller than 1.0 after being initiated (e.g., Woods, 1969; Müllemann et al., 2003). Regarding potential temperatures, it is interesting to identify regions with a vertical gradient close to zero $\left(\frac{\partial \theta}{\partial z} \rightarrow 0\right)$ since this indicates mixing over a specific altitude range.

During flight RF16, 15 dropsondes were launched in the near-upstream region at the western edge of the mountains, above and at the east side of the mountains. Example profiles of temperature and wind measurements as well as the derived potential temperature and Richardson number of one dropsonde launched at 07:55 UTC (during FF05) are shown in Fig. 7a. The position of the launch above the Southern Alps at $+69 \mathrm{~km}$ distance $\left(44.39^{\circ} \mathrm{S}, 169.60^{\circ} \mathrm{E}\right)$ is marked in Fig. 1 with a red dot. The thermal tropopause is found at an altitude of $10.6 \mathrm{~km}$, which is consistent with the WRF model calculations and is shown by the horizontal red dotted line in Fig. 7a. In the vicinity of the thermal tropopause we find a strong vertical shear of the horizontal wind (approximately $0.02 \mathrm{~s}^{-1}$ ) induced by the tropospheric jet stream whose core region is located west of the Southern Island. In this region of vertical wind shear $R i$ decreases below the critical level value of 0.25 , indicating dynamic instabilities and local turbulence (Pavelin et al., 2001, 2002). Simultaneously, the gradient in the potential temperature is strongly attenuated. For altitudes below $9.2 \mathrm{~km}$, layers with $R i$ smaller than 1.0 exist, which may be evidence of further turbulence or static instabilities. In the altitude range between 9.2 and $10.2 \mathrm{~km} R i$ is clearly larger than 1.0 and the potential temperature profile shows an enhanced gradient.

In Fig. 7b, profiles of potential temperature and $R i$ of two dropsondes that were launched at the same location over the
Southern Alps (Fig. 1) at 06:52 and 11:37 UTC show the temporal evolution over the course of the IOP. Within $5 \mathrm{~h}$ the thermal tropopause descended from 11.1 to $10.4 \mathrm{~km}$. The potential temperature of the dropsonde at 11:37 UTC shows many layers with a small gradient caused by mixing processes which occurred earlier during the event. In general, the Richardson number increased in the UTLS but still shows some evidence of turbulence ( $R i$ smaller than 1.0) right below the tropopause. At the same time the vertical shear of the horizontal winds declined (not shown), which agrees with the weakening of the gravity wave event.

The layers of suggested turbulence, found in all nine dropsondes launched above the middle and eastern part of the mountains, generally have a thickness of approximately $200 \mathrm{~m}$ and are correlated with a potential temperature range of 329 to $334 \mathrm{~K}$. The gradient of the potential temperature in these layers is less than $5 \mathrm{~K} \mathrm{~km}^{-1}$. This low gradient may be a result of initiated mixing of air masses by local turbulence.

Upstream of the mountains, wind shear regions and dynamic instabilities are not as obvious as over the middle and eastern mountains (not shown) indicating that this feature is mainly caused by the mountain waves.

Another characteristic factor is the Scorer parameter $\ell$ that is shown in Fig. 7c for the dropsonde launched at 07:55 UTC $\left(44.39^{\circ} \mathrm{S}, 169.60^{\circ} \mathrm{E}\right)$. The Scorer parameter is used to estimate the critical horizontal wavelengths, allowing vertical propagation of linear gravity waves under the given atmospheric conditions. The vertical profile of $\ell$ shows that gravity waves with horizontal wavelengths between 10 and $20 \mathrm{~km}$ are able to propagate vertically if they are excited in the lower troposphere. Between 4 and $9 \mathrm{~km}$ altitude, wave modes with horizontal wavelengths smaller than the critical wavelength of about $22 \mathrm{~km}$ become evanescent and may be attenuated. The magnitude of the estimated critical wavelength based on the Scorer parameter confirms our observations in the power spectra and wavelet cospectrum (Fig. 5): the upward transport of water vapor is dominated by horizontal wavelengths larger than $22 \mathrm{~km}$. A downward transport is possible by wavelengths smaller than $22 \mathrm{~km}$ due to a wave attenuation in the upper troposphere that is responsible for damping 

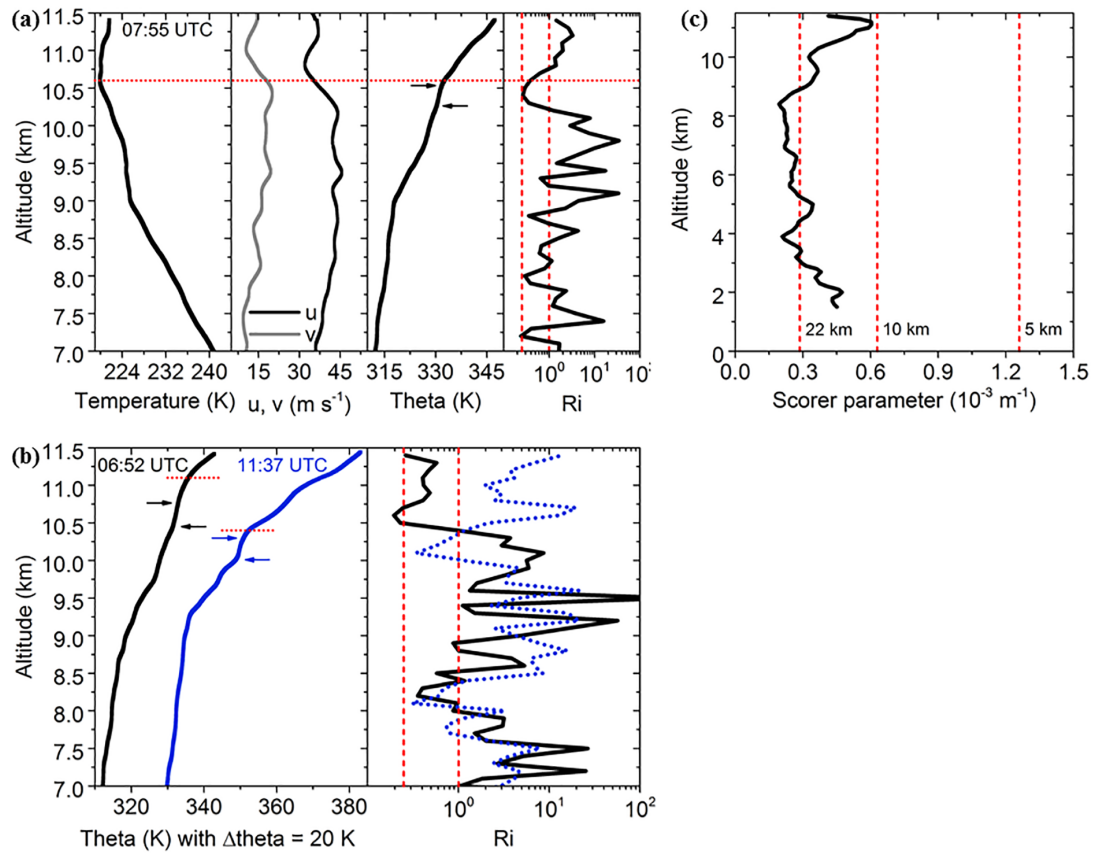

Figure 7. Dropsonde launches from $12.2 \mathrm{~km}$ height during the GV flight RF16. The panels in (a) represent the profiles of temperature, potential temperature, horizontal wind components and Richardson number for GPS altitudes from 7.0 to 11.5 km for a dropsonde at 07:55 UTC. The lower panel (b) shows the profiles of potential temperature and Richardson number for dropsondes launched at the same location as the dropsonde from (a) at 06:52 UTC (black) and 11:37 UTC (blue). The red dashed lines in the right panel show critical $R i$ at 0.25 and 1.0, the arrows in the theta panel denote regions with suggested turbulence. Horizontal red dotted lines in (a) and (b) mark the height of the thermal tropopause. (c) Vertical profile of the Scorer parameter $\ell$ (smoothed with a running average) derived from the dropsonde at 07:55 UTC (see panel a). The red dashed lines show vertical profiles of the critical horizontal wavelengths $2 \pi / \ell$ of 5,10 and $22 \mathrm{~km}$.

and partial reflecting of gravity waves. The vertical profile of $\ell$ is similar for all dropsonde launches (upstream and over the mountains) and is also comparable to an upstream $\ell$ profile from the IFS forecast shown in Fig. $3 \mathrm{~b}$ in Bramberger et al. (2017).

\section{Mixing identified by tracer-tracer correlation}

Tracer-tracer correlations are widely used to investigate mixing of trace gases and thus can support our findings presented in the previous sections. We use the correlation between water vapor and ozone, where water vapor has a strong negative gradient in the troposphere and ozone a strong positive gradient in the lower stratosphere. In Fig. 8 we show the $\mathrm{H}_{2} \mathrm{O}-\mathrm{O}_{3}$ correlation of an unperturbed non-gravity wave Falcon flight (FF03 on 2 July 2014) and of the gravity wave flights FF04 and FF05 on 4 July 2014. The flight pattern of FF03, the only flight under non-gravity wave conditions in the UTLS throughout the campaign, is similar to the gravitywave flights, with four transects over the Southern Alps at different altitudes.

The $\mathrm{H}_{2} \mathrm{O}-\mathrm{O}_{3}$ correlation in unperturbed conditions (grey dots) shows a clear $\mathrm{L}$ shape, indicating very little or no mixing of air masses. In contrast, the $\mathrm{H}_{2} \mathrm{O}-\mathrm{O}_{3}$ correlation in the
UTLS region on 4 July deviates from the $L$ shape. This indicates mixing in the tropopause region, which is most likely related to the mountain waves as shown in the previous section. The mixing is strong at potential temperatures between 329 and $334 \mathrm{~K}$ in the UTLS region, as identified by local turbulence in the dropsonde data. The dropsondes, covering a time range of $5 \mathrm{~h}$ before, during and after the second Falcon flight FF05, always show turbulence in the same potential temperature range with slight changes in the altitude due to the descent of the thermal tropopause. Thus, we also assume the presence of turbulence layers for similar potential temperatures during the first Falcon flight FF04. This potential temperature range is marked in the ozone measurements at $10.8 \mathrm{~km}$ altitude for flight FF04 over the middle and eastern part of the mountains (Fig. 8b, inlay) where we also observed the highest mountain wave activity (Sect. 4.3). Furthermore, in Sect. 4.4 we suggested that there are enhanced mixing ratios at this altitude by the shape of the vertical profile. By looking into the data in the mixing region (60-160 ppbv $\mathrm{O}_{3}$ and 8-11 ppmv $\mathrm{H}_{2} \mathrm{O}$ ) in Fig. 8b, we also find data points beyond the defined potential temperature range for mixing (329-334 K) (green dots). These data are located over the upstream region on the flown transect. They are not following the ideal L shape for no mixing but have less enhanced water vapor mixing ratios than the mixed data points (red dots). 

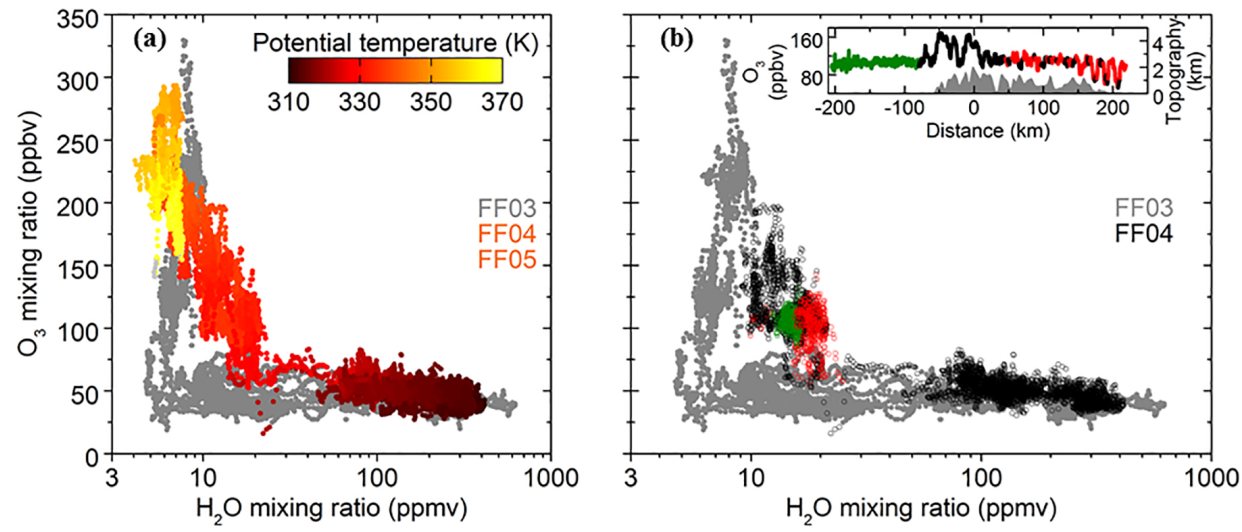

Figure 8. $\mathrm{H}_{2} \mathrm{O}-\mathrm{O}_{3}$ correlation for three Falcon flights: (a) FF04 and FF05 in mountain wave conditions and FF03 in unperturbed conditions. Potential temperature is color-coded for FF04 and FF05. (b) FF04 with a red-marked region for potential temperatures between 329 and $334 \mathrm{~K}$ that correspond to regions where turbulence in the dropsonde data of flight RF16 was observed. The inlay in (b) gives the ozone mixing ratio of flight FF04 leg 3 at $10.8 \mathrm{~km}$. The red data points show the localization of potential temperatures between 329 and $334 \mathrm{~K}$ in the ozone data and green data points mark the upstream region of this flight leg.

The same observation is found for flight FF05 at $10.8 \mathrm{~km}$ altitude but for higher ozone and lower water vapor mixing ratios since the tropopause was located at a lower altitude. Furthermore, we also suggest local turbulence and induced mixing over the mountain region for the first Falcon flight due to a similar mountain wave activity.

While the pure kinetic transport of water vapor by waves might in general be reversible, mixing implies a permanent change in the water vapor distribution in the UTLS region. The combined analysis of in situ aircraft measurements and dropsonde data shows a transport of water vapor through the upper troposphere and lower stratosphere and a partial mixing of the air masses caused by mountain waves.

\section{Effect on the atmospheric radiation budget}

The water vapor mixing ratio in the UTLS strongly influences the radiative transfer in this region. Here, we try to derive an estimate of the radiative forcing by the enhanced water vapor mixing ratios in the UTLS caused by the mountain waves based on simulations by Riese et al. (2012). They studied the influence of uncertainties in the atmospheric mixing strength on global UTLS distributions and the associated radiative effects of water vapor and other trace species. To this end, Riese et al. (2012) used multiannual simulations with the Chemical Lagrangian Model of the Stratosphere, CLaMS (McKenna et al., 2002a, b). In their Fig. 6, Riese et al. (2012) show the radiative effects at the top of the atmosphere of a certain change in water vapor mixing ratios for the year 2003. For our flight conditions (approximately $300 \mathrm{hPa}$ ) and location (New Zealand, $-45^{\circ}$ latitude), a $10 \%$ increase in water vapor mixing ratios near the tropopause results in a radiative forcing of 0.5 to $1 \mathrm{~W} \mathrm{~m}^{-2}$. The percentage change between the reference and the enhanced mixing case is derived from
Fig. 5 in Riese et al. (2012). For our case, from the water vapor to ozone correlation we assume a minimum increase of 4 ppmv $(\sim 30 \%) \mathrm{H}_{2} \mathrm{O}$ in the mixed mountain wave region (red dots in Fig. 8b) with respect to the less influenced upstream region (green dots). Under the assumption that the simulated difference in the distribution of water vapor as a result of enhanced mixing may also be representative for our case of mixing induced by mountain waves, we estimate a radiative forcing larger than $1 \mathrm{~W} \mathrm{~m}^{-2}$ locally above New Zealand during and after the mountain wave event. Riese et al. (2012) do not give a physical reason for the changes in the mixing strength, so our case may present a physical process (among other processes) contributing to the change in the water vapor distribution in the UTLS. While we used the calculations by Riese et al. (2012) at the measurement location, their study has a coarser vertical and horizontal resolution and is averaged over 1 year. Here we neglect the seasonality in the water vapor mixing ratio that is present in the Southern Hemisphere at this latitude range. Thus, our estimate has a large uncertainty. Nevertheless, it emphasizes the relevance of mountain waves on the water vapor distribution and the radiation budget of the UTLS. An upper estimate of the radiative forcing for this case may be determined by the difference between the unperturbed conditions in flight FF03 and the mixed conditions in flights FF04 and FF05. The increase in water vapor mixing ratio of $\sim 11 \mathrm{ppmv}(160 \%)$ may result in a significantly larger local radiative forcing. While the analysis of Riese et al. (2012) reflects the impact of uncertainty in the atmospheric mixing strength in the UTLS region on a global and multiannual scale, we use it here to derive a rough estimate of the local radiative effects of mountain waves for a short time period (a few hours to 1 day). Further studies are required to evaluate the radiative forcing caused by changes in the water vapor mixing ratios due to gravity 
waves in more detail. However, our crude estimate shows that mountain waves have a great potential to change the water vapor distribution of the UTLS with significant effects on climate.

\section{Conclusion and outlook}

Based on in situ aircraft measurements of water vapor and wind during the DEEPWAVE campaign, we combined selected methods to investigate the vertical transport of water vapor induced by mountain waves. Flux calculations showed regions with enhanced mountain wave activity above the Southern Alps on 4 July 2014. While the meteorology of this day and the propagation of the observed mountain waves is also discussed in Bramberger et al. (2017) and Smith et al. (2016), we concentrated on the effect of the mountain wave activity on the water vapor distribution in the UTLS. Stimulated by the flux calculation method by Shapiro (1980) and Schilling et al. (1999), we, for the first time, used in this study water vapor as a transport tracer in a wide altitude range throughout the UTLS.

Significant vertical water vapor fluxes observed by the Falcon and the GV at different flight altitudes below and above the tropopause indicated mountain wave propagation and water vapor transport through the tropopause. Forced by a strong south-westerly wind, the mountain wave activity was highest in the middle and eastern part over the Southern Alps. A wavelet analysis helped to identify the location, the direction and the horizontal wavelength scale of the observed transport process. Covering the wavelength range of $300 \mathrm{~m}$ to $80 \mathrm{~km}$, we found an upward transport of water vapor above the mountains at horizontal wavelengths between 22 and 60 at $8.9 \mathrm{~km}$ flight altitude. Further east a downward transport at smaller wavelengths $<22 \mathrm{~km}$ occurred. Thus, the water vapor transport happened at the same horizontal wavelengths as the energy and momentum transport for this case (Smith et al., 2016). The vertical profile of the Scorer parameter determined from dropsonde launches confirms a vertical propagation of horizontal wavelengths larger than $10 \mathrm{~km}$. However, wavelengths smaller than the critical wavelength of about $20 \mathrm{~km}$ may be damped and partially reflected in the upper troposphere.

The vertical flux divergence over the mountains within the altitude range 8.9 to $13.0 \mathrm{~km}$ suggests dominating upward water vapor transport through the tropopause, with enhanced mixing ratios at around $10.8 \mathrm{~km}$ altitude and below. A downward transport in the layer between 10.8 and $12 \mathrm{~km}$ occurred for horizontal wavelengths $<22 \mathrm{~km}$ and may be related to turbulence we observed in the dropsonde data. While Smith et al. (2016) and Smith and Kruse (2017) showed that there is no energy and momentum flux for these small-scale waves, we observed that a mass transport of water vapor occurred on small scales. This may point to more complex transport mechanisms of trace gases in mountain waves. To obtain the vertical water vapor flux, we neglected horizontal and vertical advection in the measurement region, but there were hints for additional transport processes such as convection or advection induced by the tropospheric jet stream, especially in the upstream region. These processes may also influence the measurements above the Southern Alps but they should be dominated by the vertical transport induced by the mountain waves. The occurrence of lee wave clouds at the lowest flight altitude $(7.7 \mathrm{~km})$ during a short time period of the first Falcon flight may additionally influence the vertical water vapor flux at $8.9 \mathrm{~km}$ by reducing its magnitude in the eastern part of the mountains. Since there is a time shift between the measurements at both altitudes and a vertical layer of more than $1 \mathrm{~km}$ between them without cloud observations, we cannot quantify the effect in this study.

In addition we investigated mixing processes induced by the mountain waves. We found indications for turbulence in dropsonde data collected over the mountain transect. Wind shear, located near and below the thermal tropopause, resulted in Richardson numbers $<1.0$, relevant for turbulence. We detected enhanced turbulence over few hours related to high mountain wave activity which induced mixing of water vapor in the upper troposphere over the Southern Alps. In addition the $\mathrm{H}_{2} \mathrm{O}-\mathrm{O}_{3}$ correlation showed enhanced mixing for the mountain wave situation compared to unperturbed conditions. Thus, we explain the water vapor distribution in the UTLS for this case by a combination of vertical transport of water vapor and mixing, both related to the observed mountain waves.

The enhanced water vapor mixing ratios in the tropopause region strongly influences the radiative transfer in the UTLS. The estimated radiative forcing for our case, locally and temporally limited over the Southern Alps of New Zealand, exceeded $1 \mathrm{~W} \mathrm{~m}^{-2}$ and suggests that mountain waves, occurring in many locations all over the world, may have a nonnegligible effect on climate.

Further studies and simulations, e.g., with the WRF model (Wagner et al., 2017), can help to enhance our understanding of the main transport and mixing processes. For example, the influence of wind shear near the tropopause and resulting small-scale turbulence may be further investigated. Regional and global modeling could help to quantify the global changes in the UTLS water vapor distribution caused by mountain waves and their effects on the atmospheric radiation budget.

Generally, the application of our novel combination of methods to a broader data set can help to better understand the mountain-wave-induced change in the water vapor distribution of the UTLS and their impact on the atmospheric radiation budget.

Data availability. DEEPWAVE data are maintained and stored by NCAR and are available at https://www.eol.ucar.edu/field projects/deepwave. Digital object identifiers (DOIs) are as- 
signed to some data sets: Falcon CR-2 data - https://doi.org/ 10.5065/D6GM85H9 (Voigt et al., 2016); (ii) GV in situ measurements - https://doi.org/10.5065/D66Q1V8B (UCAR/NCAR, 2015a); (iii) GV VCSEL measurements - https://doi.org/10.5065/ D6BG2M1H (UCAR/NCAR, 2015b); and (iv) dropsondes - https: //doi.org/10.5065/D6XW4GTB (UCAR/NCAR, 2016).

Competing interests. The authors declare that they have no conflict of interest.

Special issue statement. This article is part of the special issue "Sources, propagation, dissipation and impact of gravity waves (ACP/AMT inter-journal SI)". It is not associated with a conference.

Acknowledgements. Part of this research was funded by the German research initiative "Role of the Middle Atmosphere in Climate (ROMIC/01LG1206A)" of the German Ministry of Research and Education in the project "Investigation of the life cycle of gravity waves (GW-LCYCLE)". Further, the Deutsche Forschungsgemeinschaft (DFG) supported this work via the SFB MS-GWaves (GW-TP/DO 1020/9-1, PACOG/RA 1400/6-1) and the HALO-SPP 1294 (grant no. VO 1504/4-1). The US research was funded by NSF and NCAR/EOL. Christiane Voigt appreciates support by the Helmholtz Association under grant no. W2/W3-60. We thank the DLR flight department for excellent support of the campaign. The observational data are available at https://halo-db.pa.op.dlr.de/ and http://data.eol.ucar.edu. Michael Lichtenstern and Monika Scheibe did the ozone measurements during the campaign. Many thanks to Peter Hoor and his group from University of Mainz for the constructive discussion about trace gas transport influenced by mountain waves. The first author also wants to thank Ron Smith for helpful hints on the data analysis and Sonja Gisinger for proofreading. We thank the anonymous referees for their helpful comments on the paper.

The article processing charges for this open-access publication were covered by a Research

Centre of the Helmholtz Association.

Edited by: Jörg Gumbel

Reviewed by: two anonymous referees

\section{References}

Bramberger, M., Dörnbrack, A., Bossert, K., Ehard, B., Fritts, D. C., Kaifler, B., Mallaun, C., Orr, A., Pautet, P. D., Rapp, M., Taylor, M. J., Vosper, S., Williams, B., and Witschas, B.: Does strong tropospheric forcing cause largeamplitude mesospheric gravity waves? - A DEEPWAVE Case Study, J. Geophys. Res.-Atmos., 122, 11422-11443, https://doi.org/10.1002/2017JD027371, 2017.

Danielsen, E. F., Hipskind, R. S., Starr, W. L., Vedder, J. F., Gaines, S. E., Kley, D., and Kelly, K. K.: Irreversible Transport in the Stratosphere by Internal Waves of Short Verti- cal Wavelength, J. Geophys. Res.-Atmos., 96, 17433-17452, https://doi.org/10.1029/91jd01362, 1991.

Ehard, B., Kaifler, B., Kaifler, N., and Rapp, M.: Evaluation of methods for gravity wave extraction from middle-atmospheric lidar temperature measurements, Atmos. Meas. Tech., 8, 46454655, https://doi.org/10.5194/amt-8-4645-2015, 2015.

Ehard, B., Achtert, P., Dörnbrack, A., Gisinger, S., Gumbel, J., Khaplanov, M., Rapp, M., and Wagner, J.: Combination of Lidar and Model Data for Studying Deep Gravity Wave Propagation, Mon. Weather Rev., 144, 77-98, https://doi.org/10.1175/mwr-d14-00405.1, 2016.

Fischer, H., Wienhold, F. G., Hoor, P., Bujok, O., Schiller, C., Siegmund, P., Ambaum, M., Scheeren, H. A., and Lelieveld, J.: Tracer correlations in the northern high latitude lowermost stratosphere: Influence of cross-tropopause mass exchange, Geophys. Res. Lett., 27, 97-100, https://doi.org/10.1029/1999gl010879, 2000.

Fritts, D. C. and Alexander, M. J.: Gravity wave dynamics and effects in the middle atmosphere, Rev. Geophys., 41, 1003, https://doi.org/10.1029/2001rg000106, 2003.

Fritts, D. C., Smith, R. B., Taylor, M. J., Doyle, J. D., Eckermann, S. D., Dörnbrack, A., Rapp, M., Williams, B. P., Pautet, P. D., Bossert, K., Criddle, N. R., Reynolds, C. A., Reinecke, P. A., Uddstrom, M., Revell, M. J., Turner, R., Kaifler, B., Wagner, J. S., Mixa, T., Kruse, C. G., Nugent, A. D., Watson, C. D., Gisinger, S., Smith, S. M., Lieberman, R. S., Laughman, B., Moore, J. J., Brown, W. O., Haggerty, J. A., Rockwell, A., Stossmeister, G. J., Williams, S. F., Hernandez, G., Murphy, D. J., Klekociuk, A. R., Reid, I. M., and Ma, J.: The Deep Propagating Gravity Wave Experiment (DEEPWAVE): An Airborne and Ground-Based Exploration of Gravity Wave Propagation and Effects from Their Sources throughout the Lower and Middle Atmosphere, B. Am. Meterol. Soc., 97, 425-453, https://doi.org/10.1175/Bams-D-14$00269.1,2016$.

Geller, M. A., Alexander, M. J., Love, P. T., Bacmeister, J., Ern, M., Hertzog, A., Manzini, E., Preusse, P., Sato, K., Scaife, A. A., and Zhou, T. H.: A Comparison between Gravity Wave Momentum Fluxes in Observations and Climate Models, J. Climate, 26, 6383-6405, https://doi.org/10.1175/Jcli-D-12-00545.1, 2013.

Gettelman, A., Hoor, P., Pan, L. L., Randel, W. J., Hegglin, M. I., and Birner, T.: The Extratropical Upper Troposphere and Lower Stratosphere, Rev. Geophys., 49, RG3003, https://doi.org/10.1029/2011rg000355, 2011.

Holton, J. R., Haynes, P. H., Mcintyre, M. E., Douglass, A. R., Rood, R. B., and Pfister, L.: Stratosphere-Troposphere Exchange, Rev. Geophys., 33, 403-439, https://doi.org/10.1029/95rg02097, 1995.

Hoor, P., Fischer, H., Lange, L., Lelieveld, J., and Brunner, D.: Seasonal variations of a mixing layer in the lowermost stratosphere as identified by the $\mathrm{CO}-\mathrm{O} 3$ correlation from in situ measurements, J. Geophys. Res.-Atmos., 107, D54044, https://doi.org/10.1029/2000JD000289, 2002.

Hoor, P., Gurk, C., Brunner, D., Hegglin, M. I., Wernli, H., and Fischer, H.: Seasonality and extent of extratropical TST derived from in-situ CO measurements during SPURT, Atmos. Chem. Phys., 4, 1427-1442, https://doi.org/10.5194/acp-4-1427-2004, 2004.

Howard, L. N.: Note on a paper of John W. Miles, J. Fluid Mech., 10, 509, https://doi.org/10.1017/s0022112061000317, 2006. 
Huntrieser, H., Lichtenstern, M., Scheibe, M., Aufmhoff, H., Schlager, H., Pucik, T., Minikin, A., Weinzierl, B., Heimerl, K., Fütterer, D., Rappenglück, B., Ackermann, L., Pickering, K. E., Cummings, K. A., Biggerstaff, M. I., Betten, D. P., Honomichl, S., and Barth, M. C.: On the origin of pronounced $\mathrm{O}_{3}$ gradients in the thunderstorm outflow region during DC3, J. Geophys. Res.Atmos., 121, 6600-6637, https://doi.org/10.1002/2015jd024279, 2016.

Kaufmann, S., Voigt, C., Jessberger, P., Jurkat, T., Schlager, H., Schwarzenboeck, A., Klingebiel, M., and Thornberry, T.: In situ measurements of ice saturation in young contrails, Geophys. Res. Lett., 41, 702-709, https://doi.org/10.1002/2013g1058276, 2014.

Kaufmann, S., Voigt, C., Jurkat, T., Thornberry, T., Fahey, D. W., Gao, R.-S., Schlage, R., Schäuble, D., and Zöger, M.: The airborne mass spectrometer AIMS - Part 1: AIMS- $\mathrm{H}_{2} \mathrm{O}$ for UTLS water vapor measurements, Atmos. Meas. Tech., 9, 939-953, https://doi.org/10.5194/amt-9-939-2016, 2016.

Koch, S. E., Jamison, B. D., Lu, C. G., Smith, T. L., Tollerud, E. I., Girz, C., Wang, N., Lane, T. P., Shapiro, M. A., Parrish, D. D., and Cooper, O. R.: Turbulence and gravity waves within an upper-level front, J. Atmos. Sci., 62, 3885-3908, https://doi.org/10.1175/Jas3574.1, 2005.

Krautstrunk, M. and Giez, A.: The transition from FALCON to HALO era airborne atmospheric research, in: Atmospheric Physics: Background - Methods - Trends, edited by: Schumann, U., Springer-Verlag Berlin Heidelberg, 609-624, 2012.

Lamarque, J. F., Langford, A. O., and Proffitt, M. H.: Crosstropopause mixing of ozone through gravity wave breaking: Observation and modeling, J. Geophys. Res.-Atmos., 101, 2296922976, https://doi.org/10.1029/96jd02442, 1996.

Lane, T. P. and Sharman, R. D.: Gravity wave breaking, secondary wave generation, and mixing above deep convection in a threedimensional cloud model, Geophys. Res. Lett., 33, L23813, https://doi.org/10.1029/2006g1027988, 2006.

Langford, A. O., Proffitt, M. H., VanZandt, T. E., and Lamarque, J. F.: Modulation of tropospheric ozone by a propagating gravity wave, J. Geophys. Res.-Atmos., 101, 26605-26613, https://doi.org/10.1029/96jd02424, 1996.

Mallaun, C., Giez, A., and Baumann, R.: Calibration of 3-D wind measurements on a single-engine research aircraft, Atmos. Meas. Tech., 8, 3177-3196, https://doi.org/10.5194/amt-8-3177-2015, 2015.

McKenna, D. S., Grooss, J. U., Günther, G., Konopka, P., Müller, R., Carver, G., and Sasano, Y.: A new Chemical Lagrangian Model of the Stratosphere (CLaMS) - 2. Formulation of chemistry scheme and initialization, J. Geophys. Res.-Atmos., 107, ACH 4-1-ACH 4-14, https://doi.org/10.1029/2000jd000113, 2002a.

McKenna, D. S., Konopka, P., Grooss, J. U., Günther, G., Müller, R., Spang, R., Offermann, D., and Orsolini, Y.: A new Chemical Lagrangian Model of the Stratosphere (CLaMS) - 1. Formulation of advection and mixing, J. Geophys. Res.-Atmos., 107, ACH 15-11-ACH 15-15, https://doi.org/10.1029/2000jd000114, 2002 b.

Miles, J. W.: On the stability of heterogeneous shear flows, J. Fluid Mech., 10, 496-508, https://doi.org/10.1017/S0022112061000305, 1961.

Moustaoui, M., Teitelbaum, H., van Velthoven, P. F. J., and Kelder, H.: Analysis of gravity waves during the POLINAT experiment and some consequences for stratosphere-troposphere exchange,
J. Atmos. Sci., 56, 1019-1030, https://doi.org/10.1175/15200469(1999)056<1019:Aogwdt>2.0.Co;2, 1999.

Moustaoui, M., Mahalov, A., Teitelbaum, H., and Grubišić, V.: Nonlinear modulation of $\mathrm{O}_{3}$ and $\mathrm{CO}$ induced by mountain waves in the upper troposphere and lower stratosphere during terrain-induced rotor experiment, J. Geophys. Res., 115, D19103, https://doi.org/10.1029/2009jd013789, 2010.

Müllemann, A., Rapp, M., and Lübken, F. J.: Morphology of turbulence in the polar summer mesopause region during the MIDAS/SOLSTICE campaign 2001, AdSpR, 31, 2069-2074, https://doi.org/10.1016/S0273-1177(03)00230-8, 2003.

Pan, L. L., Bowman, K. P., Shapiro, M., Randel, W. J., Gao, R. S., Campos, T., Davis, C., Schauffler, S., Ridley, B. A., Wei, J. C., and Barnet, C.: Chemical behavior of the tropopause observed during the Stratosphere-Troposphere Analyses of Regional Transport experiment, J. Geophys. Res.-Atmos., 112, D18110, https://doi.org/10.1029/2007jd008645, 2007.

Pavelin, E., Whiteway, J. A., and Vaughan, G.: Observation of gravity wave generation and breaking in the lowermost stratosphere, J. Geophys. Res.-Atmos., 106, 5173-5179, https://doi.org/10.1029/2000jd900480, 2001.

Pavelin, E., Whiteway, J. A., Busen, R., and Hacker, J.: Airborne observations of turbulence, mixing, and gravity waves in the tropopause region, J. Geophys. Res.-Atmos., 107, D104084, https://doi.org/10.1029/2001jd000775, 2002.

Placke, M., Hoffmann, P., Gerding, M., Becker, E., and Rapp, M.: Testing linear gravity wave theory with simultaneous wind and temperature data from the mesosphere, J. Atmos. Sol.-Terr. Phys., 93, 57-69, https://doi.org/10.1016/j.jastp.2012.11.012, 2013.

Portele, T. C., Dörnbrack, A., Wagner, J., Gisinger, S., Ehard, B., Pautet, P. D., and Rapp, M.: Mountain Wave Propagation under Transient Tropopsheric Forcing - A DEEPWAVE case study, Mon. Weather Rev., submitted, 2017.

Riese, M., Ploeger, F., Rap, A., Vogel, B., Konopka, P., Dameris, M., and Forster, P.: Impact of uncertainties in atmospheric mixing on simulated UTLS composition and related radiative effects, J. Geophys. Res.-Atmos., 117, D16305, https://doi.org/10.1029/2012jd017751, 2012.

Schilling, T., Lübken, F. J., Wienhold, F. G., Hoor, P., and Fischer, H.: TDLAS trace gas measurements within mountain waves over northern Scandinavia during the POLSTAR campaign in early 1997, Geophys. Res. Lett., 26, 303-306, https://doi.org/10.1029/1998g1900314, 1999.

Schumann, U., Weinzierl, B., Reitebuch, O., Schlager, H., Minikin, A., Forster, C., Baumann, R., Sailer, T., Graf, K., Mannstein, H., Voigt, C., Rahm, S., Simmet, R., Scheibe, M., Lichtenstern, M., Stock, P., Rüba, H., Schäuble, D., Tafferner, A., Rautenhaus, M., Gerz, T., Ziereis, H., Krautstrunk, M., Mallaun, C., Gayet, J.F., Lieke, K., Kandler, K., Ebert, M., Weinbruch, S., Stohl, A., Gasteiger, J., Groß, S., Freudenthaler, V., Wiegner, M., Ansmann, A., Tesche, M., Olafsson, H., and Sturm, K.: Airborne observations of the Eyjafjalla volcano ash cloud over Europe during air space closure in April and May 2010, Atmos. Chem. Phys., 11, 2245-2279, https://doi.org/10.5194/acp-11-2245-2011, 2011.

Shapiro, M. A.: Turbulent Mixing within Tropopause Folds as a Mechanism for the Exchange of ChemicalConstituents between the Stratosphere and Troposphere, J. 
Atmos. Sci., 37, 994-1004, https://doi.org/10.1175/15200469(1980)037<0994:Tmwtfa>2.0.Co;2, 1980.

Sherwood, S. C., Roca, R., Weckwerth, T. M., and Andronova, N. G.: Tropospheric Water Vapor, Convection, and Climate, Rev. Geophys., 48, RG2001, https://doi.org/10.1029/2009rg000301, 2010.

Skamarock, W. C., Klemp, J. B., Dudhia, J., Gill, D. O., Duda, M. G., Huang, X.-Y., Wang, W., and Powers, J. G.: A Description of the Advanced Research WRF Version 3, NCAR Technical Note NCAR/TN-475+STR, https://doi.org/10.5065/D68S4MVH, 2008.

Smith, R. B. and Kruse, C. G.: Broad-Spectrum Mountain Waves, J. Atmos. Sci., 74, 1381-1402, https://doi.org/10.1175/jas-d-160297.1, 2017.

Smith, R. B., Woods, B. K., Jensen, J., Cooper, W. A., Doyle, J. D., Jiang, Q. F., and Grubisic, V.: Mountain waves entering the stratosphere, J. Atmos. Sci., 65, 2543-2562, https://doi.org/10.1175/2007jas2598.1, 2008.

Smith, R. B., Nugent, A. D., Kruse, C. G., Fritts, D. C., Doyle, J. D., Eckermann, S. D., Taylor, M. J., Dörnbrack, A., Uddstrom, M., Cooper, W., Romashkin, P., Jensen, J., and Beaton, S.: Stratospheric Gravity Wave Fluxes and Scales during DEEPWAVE, J. Atmos. Sci., 73, 2851-2869, https://doi.org/10.1175/Jas-D-150324.1, 2016.

Solomon, S., Rosenlof, K. H., Portmann, R. W., Daniel, J. S., Davis, S. M., Sanford, T. J., and Plattner, G.-K.: Contributions of Stratospheric Water Vapor to Decadal Changes in the Rate of Global Warming, Science, 327, 1219-1223, https://doi.org/10.1126/science.1182488, 2010.

Teitelbaum, H., Moustaoui, M., Ovarlez, J., and Kelder, H.: The role of atmospheric waves in the laminated structure of ozone profiles at high latitude, Tellus A, 48, 442-455, https://doi.org/10.1034/j.1600-0870.1996.t01-2-00006.x, 1996.

Torrence, C. and Compo, G. P.: A practical guide to wavelet analysis, B. Am. Meterol. Soc., $\quad 79, \quad 61-78, \quad$ https://doi.org/10.1175/15200477(1998)079<0061:Apgtwa>2.0.Co;2, 1998.

UCAR/NCAR - Earth Observing Laboratory: Low Rate (LRT - 1 sps) Navigation, State Parameter, and Microphysics Flight-Level Data - IWG1 format, Version 1.2. UCAR/NCAR -Earth Observing Laboratory, https://doi.org/10.5065/D66Q1V8B (last access: 12 December 2017), 2015a.

UCAR/NCAR - Earth Observing Laboratory: High Rate (HRT - 25 sps) Navigation, State Parameter, and Microphysics Flight-Level Data, Version 1.4. UCAR/NCAR - Earth Observing Laboratory, https://doi.org/10.5065/D6BG2M1H, (last access: 12 December 2017), 2015

UCAR/NCAR - Earth Observing Laboratory: NSF/NCAR GV HIAPER QC Dropsonde Data, Version 3.0. UCAR/NCAR - Earth Observing Laboratory, https://doi.org/10.5065/D6XW4GTB (last access: 12 December 2017), 2016.

Voigt, C., Schumann, U., Jessberger, P., Jurkat, T., Petzold, A., Gayet, J. F., Krämer, M., Thornberry, T., and Fahey, D. W.: Extinction and optical depth of contrails, Geophys. Res. Lett., 38, L11806, https://doi.org/10.1029/2011gl047189, 2011.

Voigt, C., Schumann, U., Jurkat, T., Schäuble, D., Schlager, H., Petzold, A., Gayet, J.-F., Krämer, M., Schneider, J., Borrmann, S., Schmale, J., Jessberger, P., Hamburger, T., Lichtenstern, M., Scheibe, M., Gourbeyre, C., Meyer, J., Kübbeler, M., Frey, W.,
Kalesse, H., Butler, T., Lawrence, M. G., Holzäpfel, F., Arnold, F., Wendisch, M., Döpelheuer, A., Gottschaldt, K., Baumann, R., Zöger, M., Sölch, I., Rautenhaus, M., and Dörnbrack, A.: In-situ observations of young contrails - overview and selected results from the CONCERT campaign, Atmos. Chem. Phys., 10, 90399056, https://doi.org/10.5194/acp-10-9039-2010, 2010.

Voigt, C., Jessberger, P., Jurkat, T., Kaufmann, S., Baumann, R., Schlager, H., Bobrowski, N., Giuffrida, G., and Salerno, G.: Evolution of $\mathrm{CO}_{2}, \mathrm{SO}_{2}, \mathrm{HCl}$, and $\mathrm{HNO}_{3}$ in the volcanic plumes from Etna, Geophys. Res. Lett., 41, 2196-2203, https://doi.org/10.1002/2013g1058974, 2014.

Voigt, C., Schlage, R., Kaufmann, S.: DLR Falcon CR2 Data, Version 1.0. UCAR/NCAR -Earth Observing Laboratory, https://doi.org/10.5065/D6GM85H9 (last access: 12 December 2017), 2016.

Wagner, J., Dörnbrack, A., Rapp, M., Gisinger, S., Ehard, B., Bramberger, M., Witschas, B., Chouza, F., Rahm, S., Mallaun, C., Baumgarten, G., and Hoor, P.: Observed versus simulated mountain waves over Scandinavia - improvement of vertical winds, energy and momentum fluxes by enhanced model resolution?, Atmos. Chem. Phys., 17, 4031-4052, https://doi.org/10.5194/acp-17-4031-2017, 2017.

Whiteway, J. A., Pavelin, E. G., Busen, R., Hacker, J., and Vosper, S.: Airborne measurements of gravity wave breaking at the tropopause, Geophys. Res. Lett., 30, 2070 https://doi.org/10.1029/2003gl018207, 2003.

WMO: Meteorology - A three-dimensional science, WMO Bulletin, 6, 134-138, 1957.

Woods, B. K. and Smith, R. B.: Energy Flux and Wavelet Diagnostics of Secondary Mountain Waves, J. Atmos. Sci., 67, 37213738, https://doi.org/10.1175/2010jas3285.1, 2010.

Woods, J. D.: On Richardson's Number as a Criterion for Laminar-Turbulent-Laminar Transition in the Ocean and Atmosphere, Radio Sci., 4, 1289-1298, https://doi.org/10.1029/RS004i012p01289, 1969.

Wright, C. J., Hindley, N. P., Moss, A. C., and Mitchell, N. J.: Multiinstrument gravity-wave measurements over Tierra del Fuego and the Drake Passage - Part 1: Potential energies and vertical wavelengths from AIRS, COSMIC, HIRDLS, MLS-Aura, SAAMER, SABER and radiosondes, Atmos. Meas. Tech., 9, 877-908, https://doi.org/10.5194/amt-9-877-2016, 2016.

Young, K., Hock, T., and Martin, C.: DEEPWAVE 2014 Dropsonde Data Quality Report, UCAR/NCAR - Earth Observing Laboratory, 2014.

Zhang, F., Wei, J., Zhang, M., Bowman, K. P., Pan, L. L., Atlas, E., and Wofsy, S. C.: Aircraft measurements of gravity waves in the upper troposphere and lower stratosphere during the START08 field experiment, Atmos. Chem. Phys., 15, 76677684, https://doi.org/10.5194/acp-15-7667-2015, 2015.

Zondlo, M. A., Paige, M. E., Massick, S. M., and Silver, J. A.: Vertical cavity laser hygrometer for the National Science Foundation Gulfstream-V aircraft, J. Geophys. Res.-Atmos., 115, D20309, https://doi.org/10.1029/2010jd014445, 2010. 